\title{
Mathematical Description of Energy Transition Scenarios Based on the Latest Technologies and Trends
}

\author{
Askar A. Akaev * and Olga I. Davydova \\ Faculty of Global Studies, Moscow State University, 119234 Moscow, Russia; davydova.olga.msk@gmail.com \\ * Correspondence: askarakaev@mail.ru
}

\begin{abstract}
This work, dedicated to a mathematical description of energy transition scenarios, consists of three main parts. The first part describes modern trends and problems of the energy sector. A large number of charts reflecting the latest updates in energy are provided. The COVID-2019 pandemic's impacts on the energy sector are also included. The second part of the paper is dedicated to the analysis of energy consumption and the structure of the world fuel and energy balance. Furthermore, a detailed description of energy-efficient technologies is given. Being important and low-carbon, hydrogen is discussed, including its advantages and disadvantages. The last part of the work describes the mathematical tool developed by the authors. The high availability of statistical data made it possible to identify parameters used in the algorithm with the least squares method and verify the tool. Performing several not complicated steps of the algorithm, the tool allows calculating the deviation of the average global temperature of the surface atmosphere from preindustrial levels in the 21st century under different scenarios. Using the suggested mathematical description, the optimal scenario that makes it possible to keep global warming at a level below $1.7^{\circ} \mathrm{C}$ was found.
\end{abstract}

check for updates

Citation: Akaev, A.A.; Davydova, O.I. Mathematical Description of Energy Transition Scenarios Based on the Latest Technologies and Trends. Energies 2021, 14, 8360. https:// doi.org/10.3390/en14248360

Academic Editor: Gilbert Ahamer

Received: 20 October 2021

Accepted: 8 December 2021

Published: 11 December 2021

Publisher's Note: MDPI stays neutral with regard to jurisdictional claims in published maps and institutional affiliations.

Copyright: (c) 2021 by the authors. Licensee MDPI, Basel, Switzerland. This article is an open access article distributed under the terms and conditions of the Creative Commons Attribution (CC BY) license (https:// creativecommons.org/licenses/by/ $4.0 /)$.
Keywords: decarbonization; renewable energy; energy transition; energy efficiency; hydrogen; carbon capture and storage; mathematical description; parameters identification

\section{Introduction}

Over the last 70 years, carbon dioxide emissions increased by 2.2 times causing climate change. Climate change became one of the most pressing problems mankind has to face. The temperature of the Earth's atmosphere increased by more than $1^{\circ} \mathrm{C}$ compared to pre-industrial levels, while the snow on the tops of mountains and poles started to melt and the level of seawater raised. Living organisms are suffering from diseases caused by a high percentage of carbon dioxide in the air. The effects of climate change are being observed in every part of the world. Extreme weather conditions have become more rapid, severe and destructive. Droughts became more frequent in Australia, Brazil, India, the United States and other locations [1]. Many countries, including Indonesia, China, Brazil, the United Kingdom, Pakistan and others suffer from floods. Wildfires destroy large areas of forests. In 2021, 200,000 square kilometers were burned in Russia alone [2]. In 2005, Hurricane Katrina caused almost two thousand deaths and significant economic damage. In September 2017, more than three thousand people lost their lives due to Hurricane Maria [3]. Why is this happening? Is there a way to stop climate change?

For thousands of years, climate changes occurred cyclically due to natural reasons, but the tendency changed in the 1800s. Manufacturing and industry, generating electricity and heat have been the main reason for climate change, mostly due to the burning of fossil fuels. It is a known fact that long-term fossil fuel combustion contributed to the total greenhouse gas emissions. In 1965, the share of fossil fuels in energy consumption was $94 \%$. Today it has decreased to $83 \%$, but this is still too high. The world is in search of alternative heating and energy systems. In 2016, the Paris Climate Agreement of the United Nations was signed by 175 countries. It requires global warming to be maintained at the level of $1.5-2{ }^{\circ} \mathrm{C}$ in the 21 st century. To achieve this purpose, an energy transition 
to sources of energy that are renewable and do not produce harmful pollutants is needed. This transition has already begun, and the share of renewable energy in the total primary energy supply is now more than $15 \%$. Energy agencies suppose that the share of renewable energy in the total primary energy supply could reach up to $65 \%$ in $2050[4,5]$.

Many energy-efficient technologies that can help reduce carbon emissions exist. "Smart grids", hybrid electric vehicles, solar panels and wind turbines, LED lighting, white roofs, programmable heating devices and energy-saving household appliances are examples of technologies that can help to decrease carbon dioxide emissions. Big data analysis and automated management can also contribute to the keeping of global warming. Section 3 of the article includes a detailed description of energy-efficient technologies.

Dolf Gielen et al. [6] showed that if we apply the electrification of end-uses, energy efficiency technologies and renewable energy together, we can decrease emissions by up to $94 \%$.

Another clean energy source that can be used against global warming is green hydrogen. The share of green hydrogen in the energy balance may increase up to $18 \%$ in the 21 st century. Many countries already developed their hydrogen strategies.

According to the Center for Climate and Energy Solutions, carbon capture and storage can reduce greenhouse gas emissions by $14 \%$ by 2050 [7].

Thus, it is obvious that global warming can be reduced, but this requires decisive actions from policymakers and society. Numerous scenarios of global warming are discussed among scientists, but as a rule, two main scenarios are included in discussions: a conservative scenario and an ambitious scenario. A conservative scenario supposes that recently observed tendencies will remain in the future. BP forecasts that if a conservative scenario will take place, carbon emissions from energy use in 2050 will only be decreased by $10 \%$ compared to 2018 [4].

An ambitious scenario, opposite to the conservative scenario, introduces several measures that will significantly (by up to $70 \%$ ) reduce carbon emissions from energy use by 2050 [4].

A "Net Zero" scenario is also widely discussed. It requires the balance between greenhouse gases produced and removed from the atmosphere.

The authors developed a mathematical tool that allows estimating the deviation of the average global temperature of the surface atmosphere from pre-industrial levels in the 21st century. A large number of available data series and Python programming language made it possible to identify parameters used in the algorithm utilizing the least squares method, and verify the tool.

The algorithm assumes the calculation of various scenarios of population growth and the corresponding scenarios of energy demand, based on the new paradigm of energy consumption that will be introduced in Section 4, scenarios writing for the dynamics of the structure of energy consumption by types of energy sources, the calculation of the dynamics of $\mathrm{CO}_{2}$ emissions into the atmosphere, the calculation of the dynamics of $\mathrm{CO}_{2}$ accumulation in the atmosphere, and finally, the calculation of changes in the global average temperature of the surface atmosphere.

Using the suggested mathematical tool, several scenarios of the energy transition were calculated and will be demonstrated. Now, the description of the latest tendencies will be presented.

\section{The Current State of the Energy Sector}

\subsection{Modern Trends of the Energy Sector}

Analyzing statistical data, the authors show the following trends. Primary Energy consumption steadily grows; it has increased 3.5 times since 1965, which is shown in Figure 1. At the same time, decarbonization demonstrates a transition to a carbon-free economy by increasing the share of renewable energy sources (see Figure 2). Fossil fuels' long-term decline continues. 


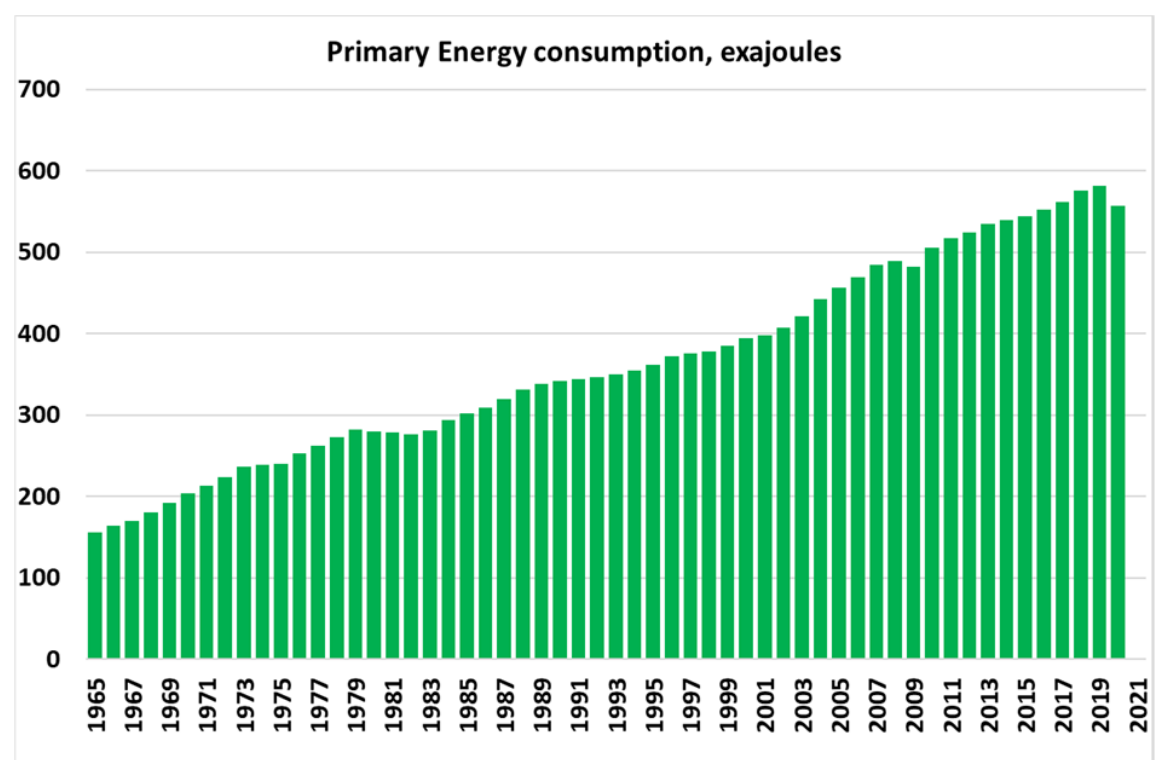

Figure 1. Primary Energy consumption, exajoules [5].

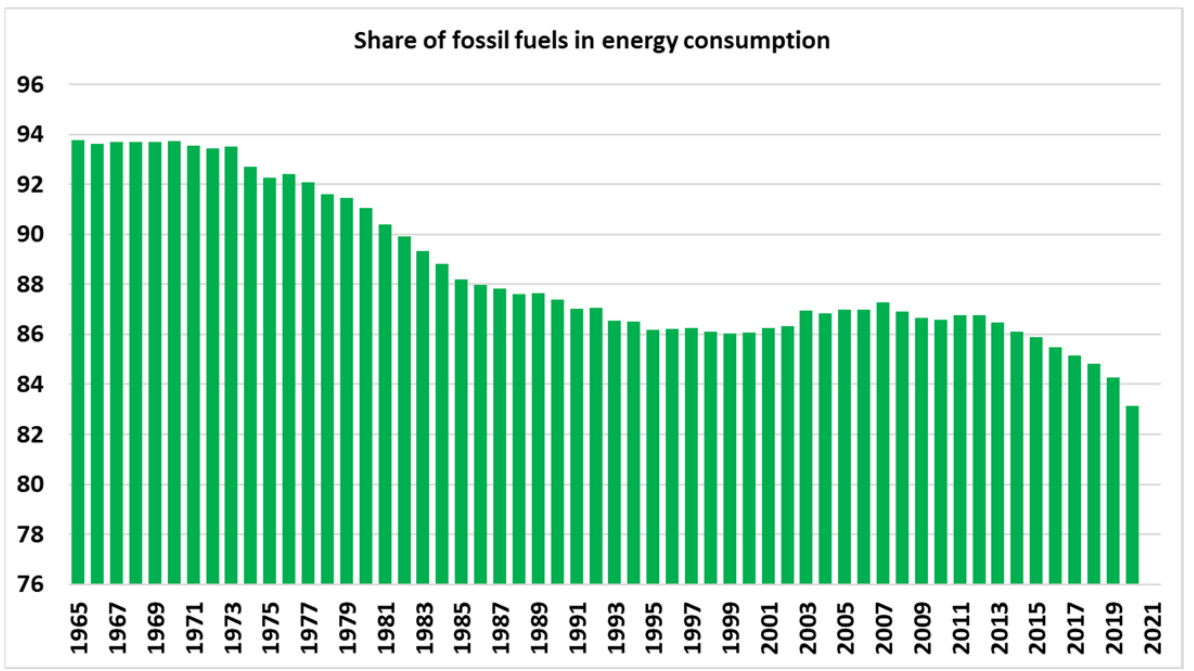

Figure 2. Share of fossil fuels in energy consumption, \% [5].

Over the last 50 years, the share of fossil fuels in energy consumption decreased by more than $10 \%$, while the share of renewables increased by 40 times. Although hydropower is good for the environment and water is a renewable resource, the share of energy generated from hydropower only increased from 6\% in 1965 to $7 \%$ in 2020. This can be explained by expensive dam building, difficulties in finding appropriate locations for dam building and the risk of dam failure [8-10]. The dynamics of changes in the structure of the world fuel and energy balance are shown in Figure 3.

Today, $44 \%$ of global $\mathrm{CO}_{2}$ emissions are generated by the electricity and heat generation sector: $26 \%$ by transport and $20 \%$ by the industry sector [11]. The technologies allowing to reduce $\mathrm{CO}_{2}$ emissions are in development. These technologies for the electricity and heat generation sector will be described below. Increasing electrification is observed in the transportation sector -10 million electric cars are now on the roads [12]. In 2010, approximately 17 thousand electric cars were on the roads. Thus, the number of electric cars has increased by over 600 times in the last 10 years. 

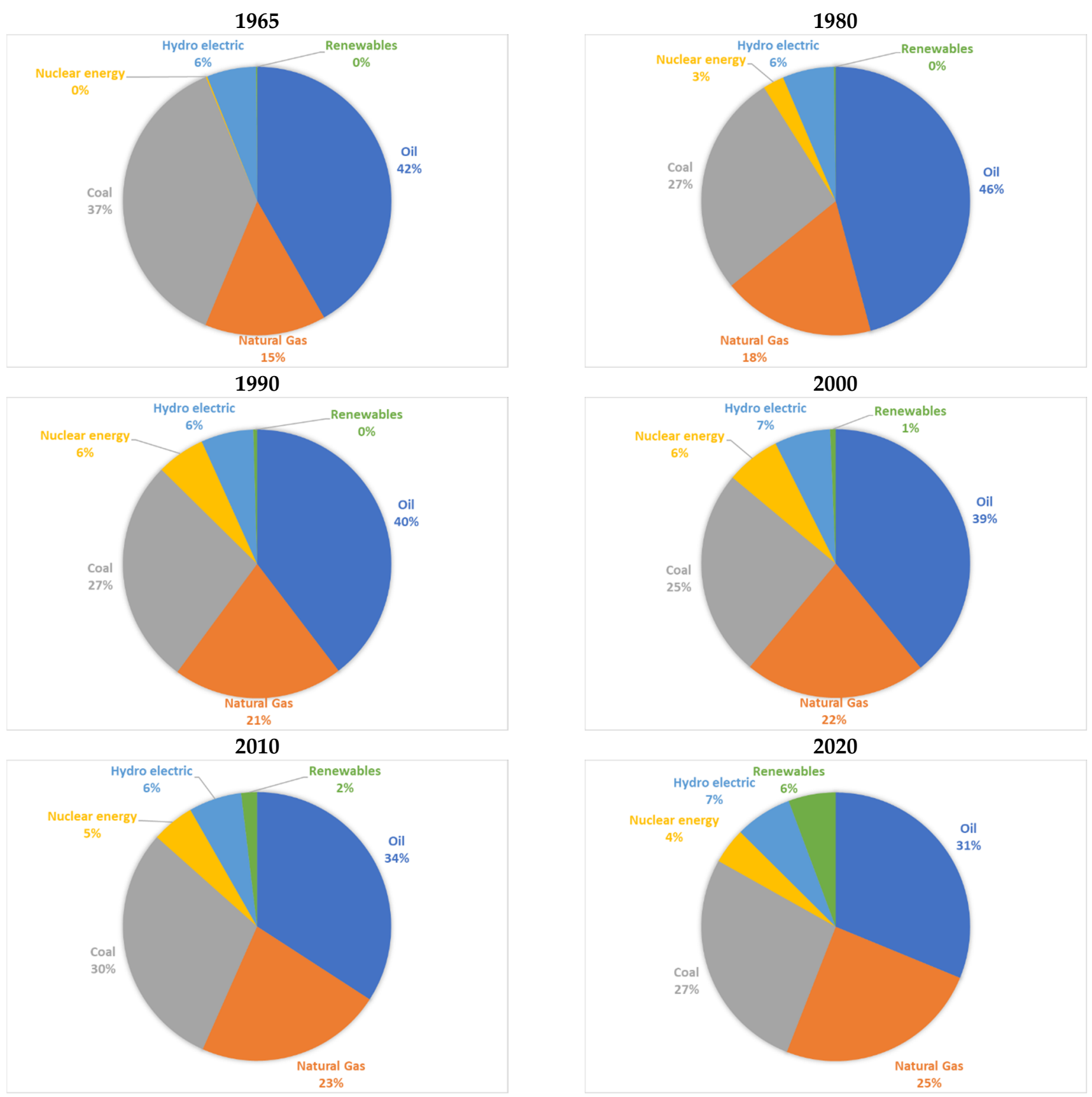

Figure 3. The dynamics of changes in the structure of the world fuel and energy balance, calculated by authors using [5].

Now, the "Net-zero emission by 2050" scenario, which assumes that the global carbon emissions from energy use will decrease by over $95 \%$ by 2050 , is becoming very important, and leading to further development. In leading countries, the share of renewables in primary energy consumption already exceeded 18\% in 2020 (see Figure 4).

It should be mentioned that global energy transition to renewable energy cannot be fast. Still, there are countries where the share of coal in primary energy consumption is larger than 50\%. The two most populous countries, China and India, are among them, which is demonstrated in Figure 5. 


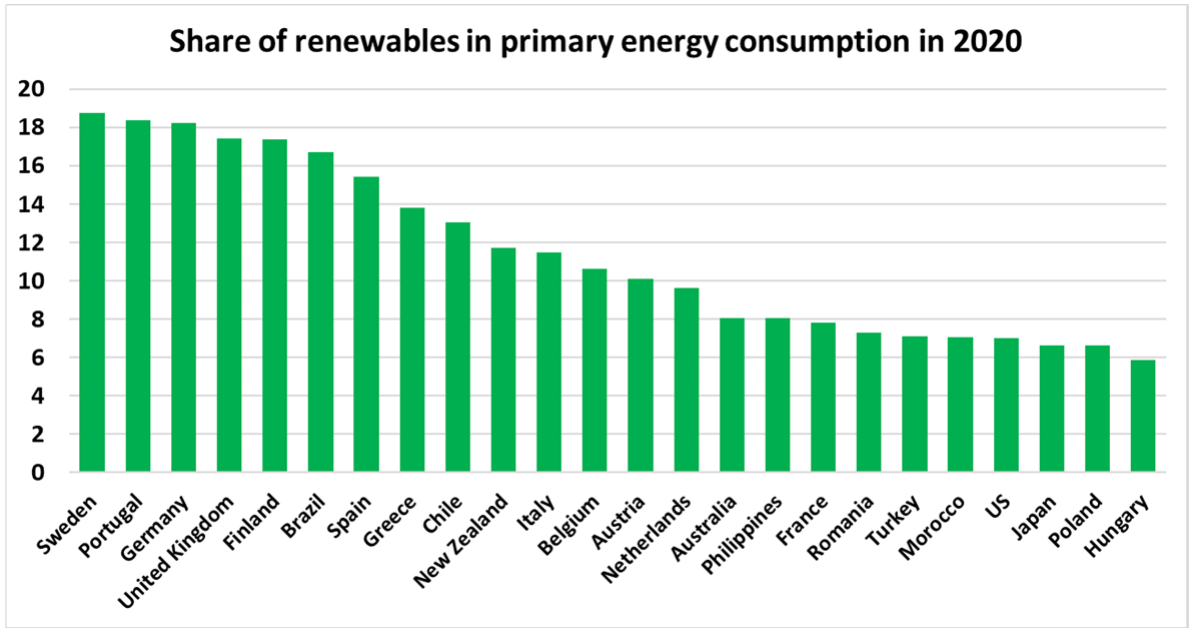

Figure 4. Countries in which the shares of renewables in primary energy consumption are the largest in $2020, \%$ [5].

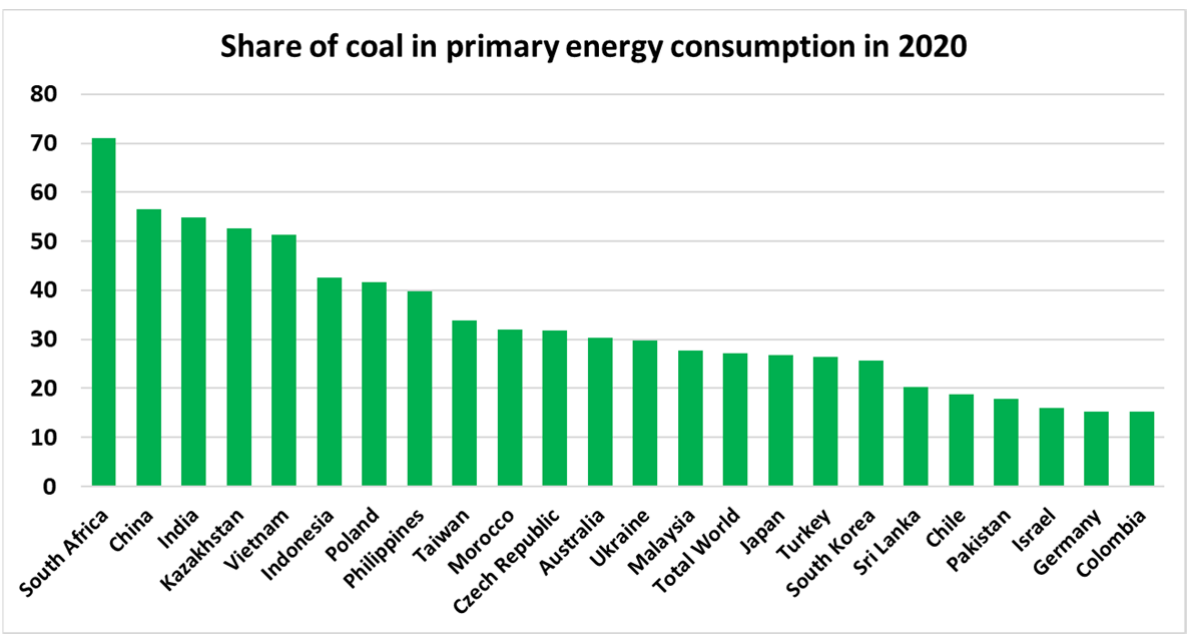

Figure 5. Countries in which the shares of coal in primary energy consumption are the largest in $2020, \%[5]$.

Furthermore, in some countries (Singapore, Trinidad and Tobago, Turkmenistan and Uzbekistan) the share of oil or natural gas in primary energy consumption still exceeds $70 \%$ (see Figures 6 and 7).

If we look at the management in the energy sector, we can see a tendency toward decentralization. Today, there are many geographically distributed electricity consumers and producers. The digitalization of the energy sector and AI-driven solutions deployment become very important. Internet of Energy, for example, allows making the transmission of energy more efficient and productive. According to the authors' calculations, energyefficient technologies make it possible to decrease real energy consumption by up to $50 \%$.

Coming back to the "Net-zero emission by 2050" scenario, it is important to notice that the role of carbon capture and storage technologies (CCS) increases. World capture and storage capacity grew up by 33\% compared to 2019. Today, 65 CCS facilities are already functioning in the world [13]. Green hydrogen also starts to play an important role in the decarbonization process. The sector that also becomes significant is the energy storage sector. 


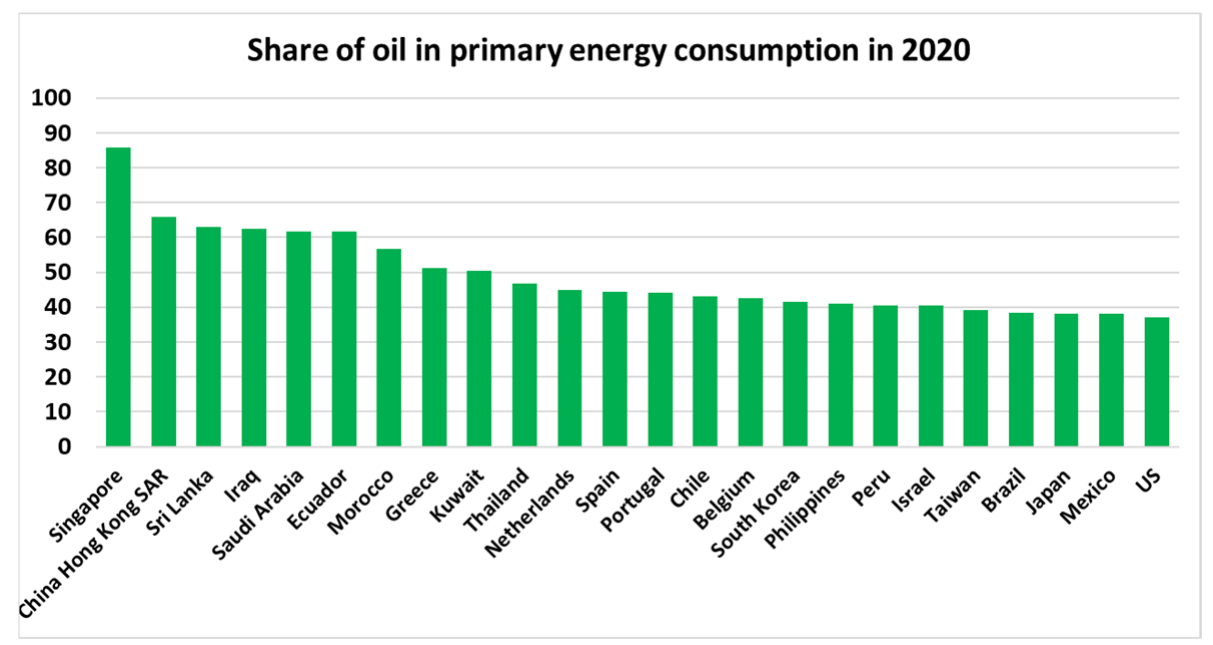

Figure 6. Countries in which the shares of oil in primary energy consumption are the largest in 2020, $\%$ [5].

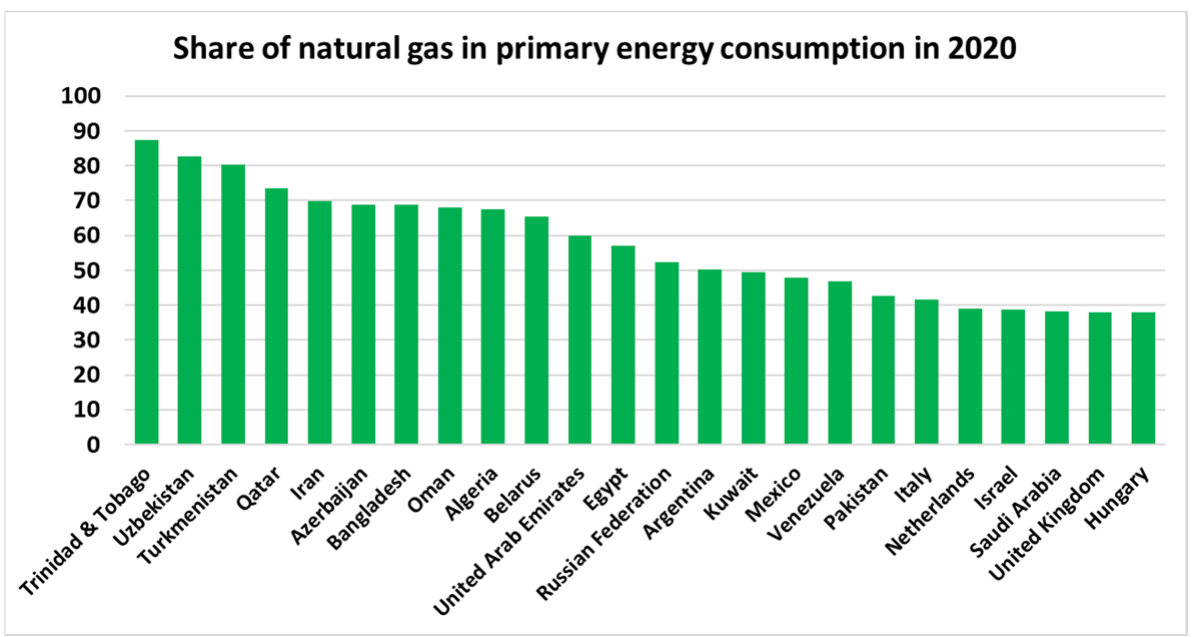

Figure 7. Countries in which the shares of natural gas in primary energy consumption are the largest in $2020, \%$ [5].

\subsection{Changes Observed in 2020}

The COVID-19 pandemic impacted the most trends that were observed in 2019 and before. Primary energy consumption and carbon dioxide emissions significantly decreased [14] (see Figure 8). Primary energy consumption in 2020 decreased by $4.3 \%$ compared to 2019, from 581.5 exajoules to 556.6 exajoules [5]. Norway, unlike most countries, increased its primary energy consumption by $8.5 \%$ in 2020 , and China by $2.4 \%$. Carbon dioxide emissions decreased by $6 \%$ compared to 2019, from 34,039.8 million tons to 31,983.6 million tons (see Figure 9). Figure 10 shows that electricity generation in 2020 decreased by $0.7 \%$ compared to 2019 , from 27,001 terawatt-hours to 26,823 terawatt-hours. At the same time, renewable energy demonstrated growth.

Let us consider changes in 2020 for the most important energy sources separately. Thus, coal consumption in 2020 decreased by $4 \%$ compared to 2019, from 157.6 exajoules to 151.42 exajoules, which accelerates the general decline of coal consumption since 2015. Oil consumption decreased by $9.5 \%$ compared to 2019, from 191.9 exajoules to 173.7 exajoules. Gas consumption decreased by $2 \%$ compared to 2019 , from 140.5 exajoules to 137.6 exajoules. Renewable energy consumption increased by $10 \%$ compared to 2019 , from 28.82 exajoules to 31.71 exajoules. Solar energy consumption increased by $20.4 \%$ compared to 2019, from 6.3 exajoules to 7.6 exajoules. Hydroelectricity consumption increased by $1.3 \%$ compared to 2019 , from 37.7 exajoules to 38.1 exajoules. Nuclear consumption 
decreased by $3.8 \%$ compared to 2019 , from 24.9 exajoules to 24 exajoules, which has accelerated the general decline of nuclear since 2003 . Wind consumption increased by $11.8 \%$ compared to 2019, from 12.6 exajoules to 14.13 exajoules. The dynamics of main energy sources consumption are shown in Figure 11.

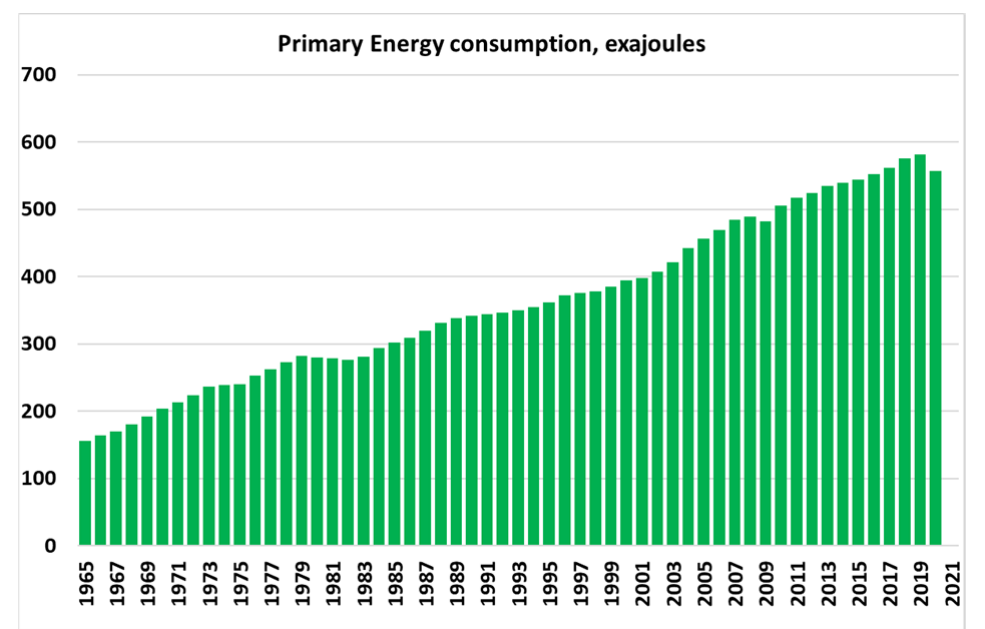

Figure 8. Primary Energy consumption, exajoules [5].

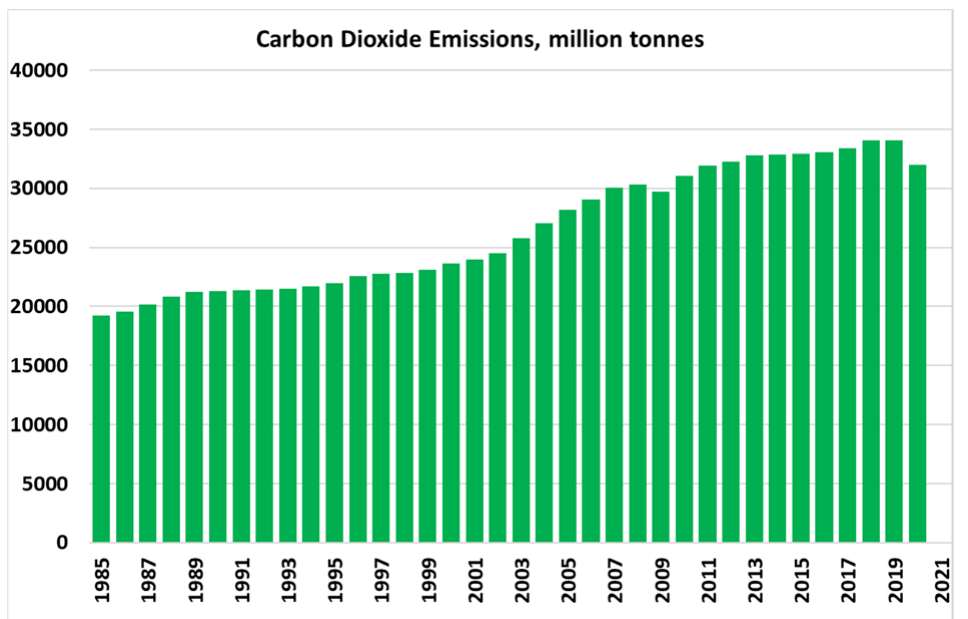

Figure 9. Carbon dioxide emissions, million tones [5].

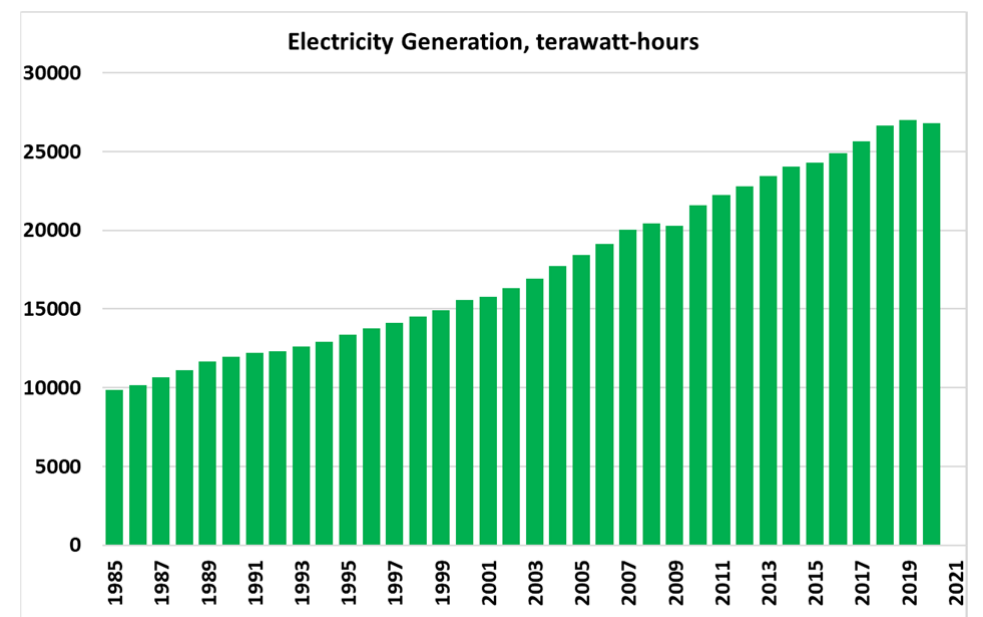

Figure 10. Electricity Generation, terawatt-hours [5]. 

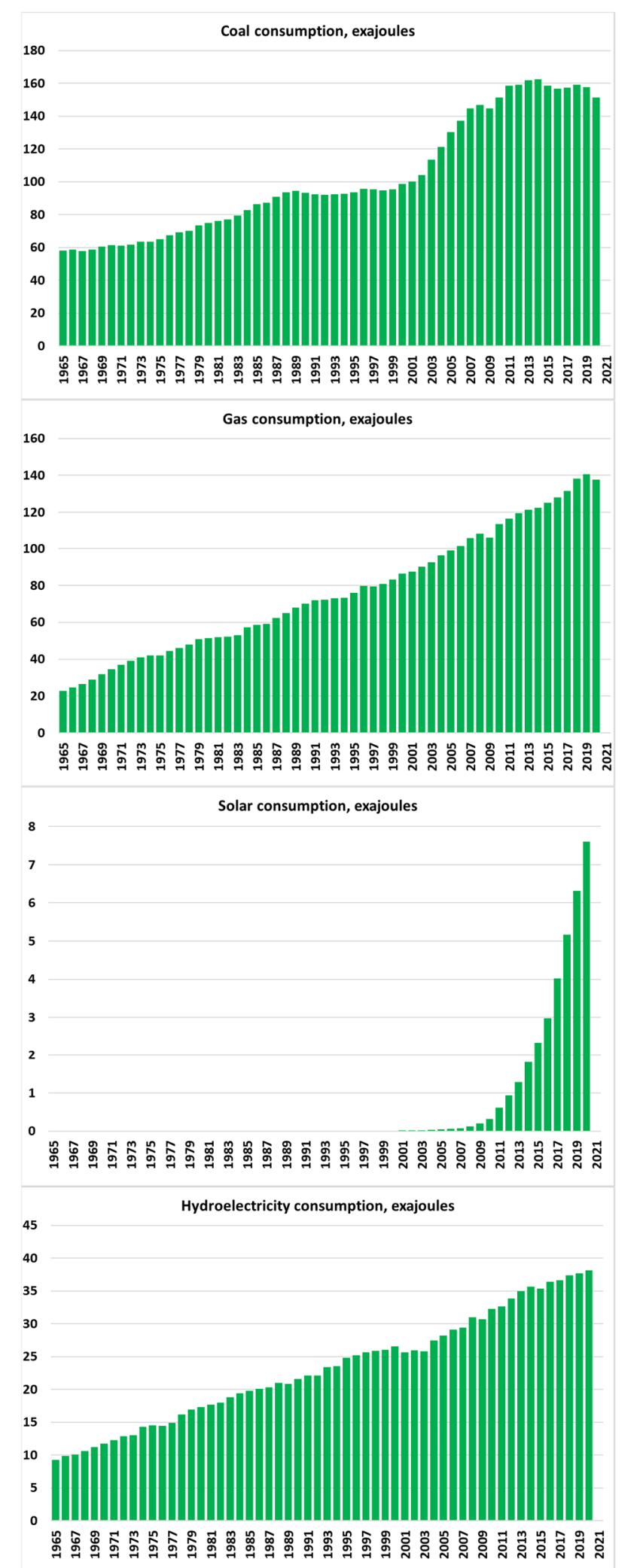
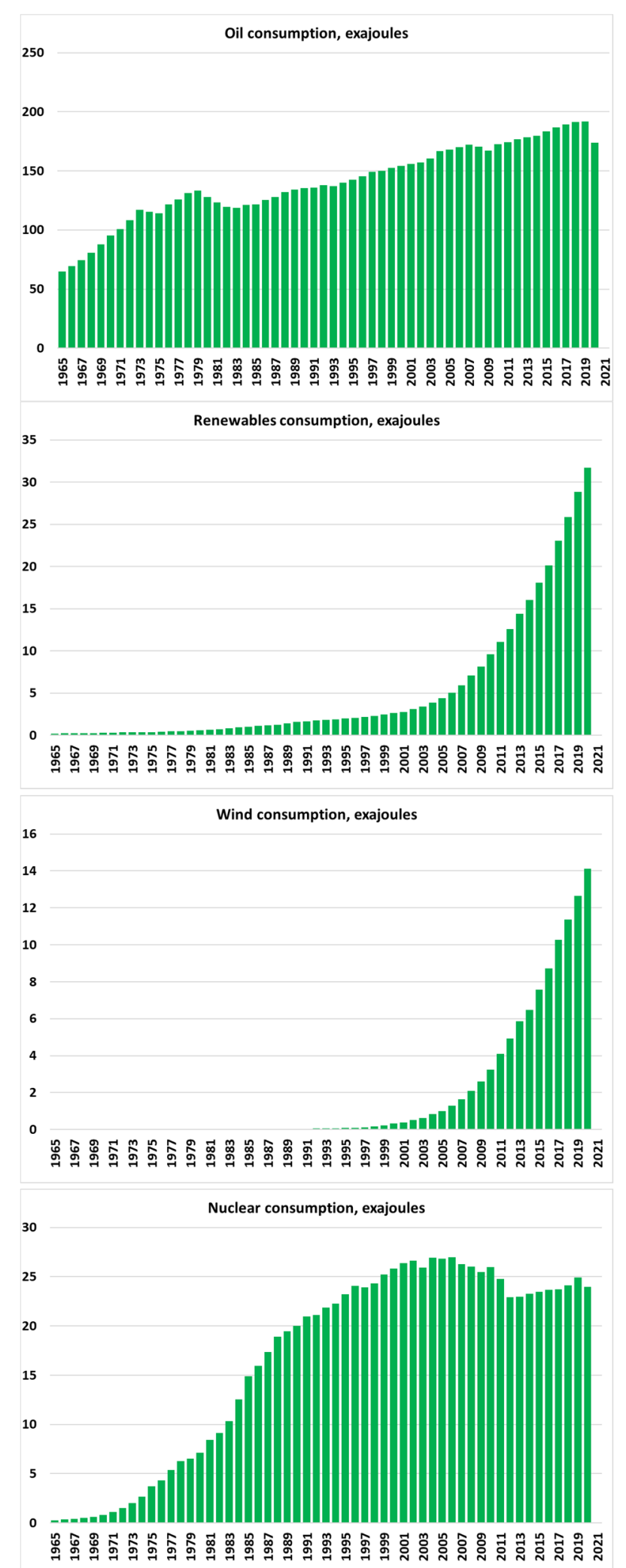

Figure 11. Energy consumption by fuels, exajoules [5].

Despite declines in energy consumption and carbon dioxide emissions in 2020, the situation in general is complex, and requires immediate actions from the global community. The temperature of the Earth's atmosphere continues to increase fast, and this must be changed. It could be changed, and the goals of the Paris agreement could be achieved 
by using several technologies and approaches, which will be discussed in the paragraph below. At the COP26 conference, taking place in November 2021 in Glasgow, countries agreed to accelerate the phase-out of coal, which causes $40 \%$ of annual $\mathrm{CO}_{2}$ emissions and a phase-out of fossil fuel subsidies [15]. An accelerated shift away from fossil fuels and towards renewable energy was declared.

\section{Ways of Reducing Global Warming}

Authors consider the following ways of reducing global warming:

- energy-efficient technologies;

- renewable energy;

- green hydrogen;

- CCS technology

\subsection{Energy-Efficient Technologies}

There is a large set of energy-efficient technologies that contribute to carbon emissions' decrease. In this paragraph, examples of such energy technologies will be described, including energy-saving technologies for the home.

A "smart grid" is determined as an electricity network that utilizes advanced technologies (including AI technologies) for managing electricity transport from all sources to electricity consumers [16]. Because of strong communication between the grid's elements (electricity producers, consumers, storage devices, network infrastructure), the effective functioning of the system is provided [17]. In such a system, an adaptation of the load profile is possible, namely by shifting peak load towards other times in the days with lower load. Moreover, "smart grids" control energy stores such as pumped hydropower stations that allow storing excess energy for days, or even a year. "Smart devices-consumers of energy" make it possible not only to receive electricity, but also to give it to the network if necessary.

Hybrid electric vehicles already reached up to $65 \%$ more fuel-efficiency than petrolfueled vehicles. Petrol-fueled vehicles also consume four times more energy compared to pure electric vehicles [18]. In 2019, more than 2 million new electric cars were sold globally [19] (p. 248) (see Figures 12 and 13).

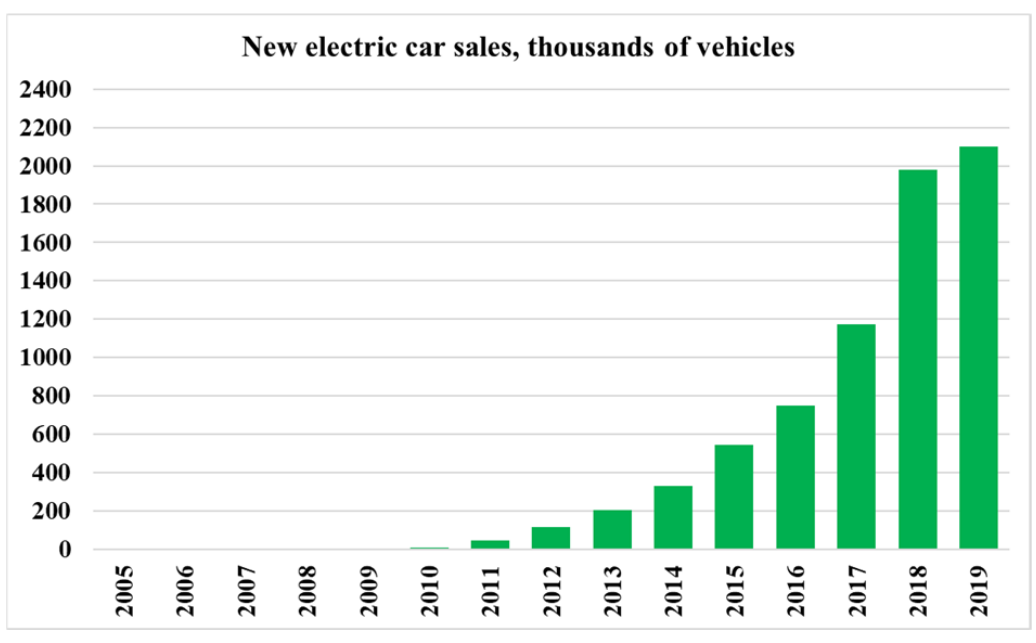

Figure 12. New electric car sales, thousands of vehicles [19] (p. 248).

The use of environmentally friendly renewable solar energy to provide a million homes with energy can reduce carbon dioxide emissions by 4.3 million tons per year [20], by more than $1350 \mathrm{~kg}$ in just one household. The use of electricity generated by solar panels allows less electricity consumption from the general network, and reduces costs. Having sufficient capacity in the home system allows to sell the electricity generated by the energy of the sun. Solar panels provide energy independence. There will always be electricity 
in a house or an enterprise when the sun is shining in the sky (if there are additional batteries, also at night). Most solar panels are very reliable and designed for more than 20 years, during which the system requires minimal maintenance and does not need high operating costs. Owners of solar power plants can also count on support from the state (subsidies, benefits).

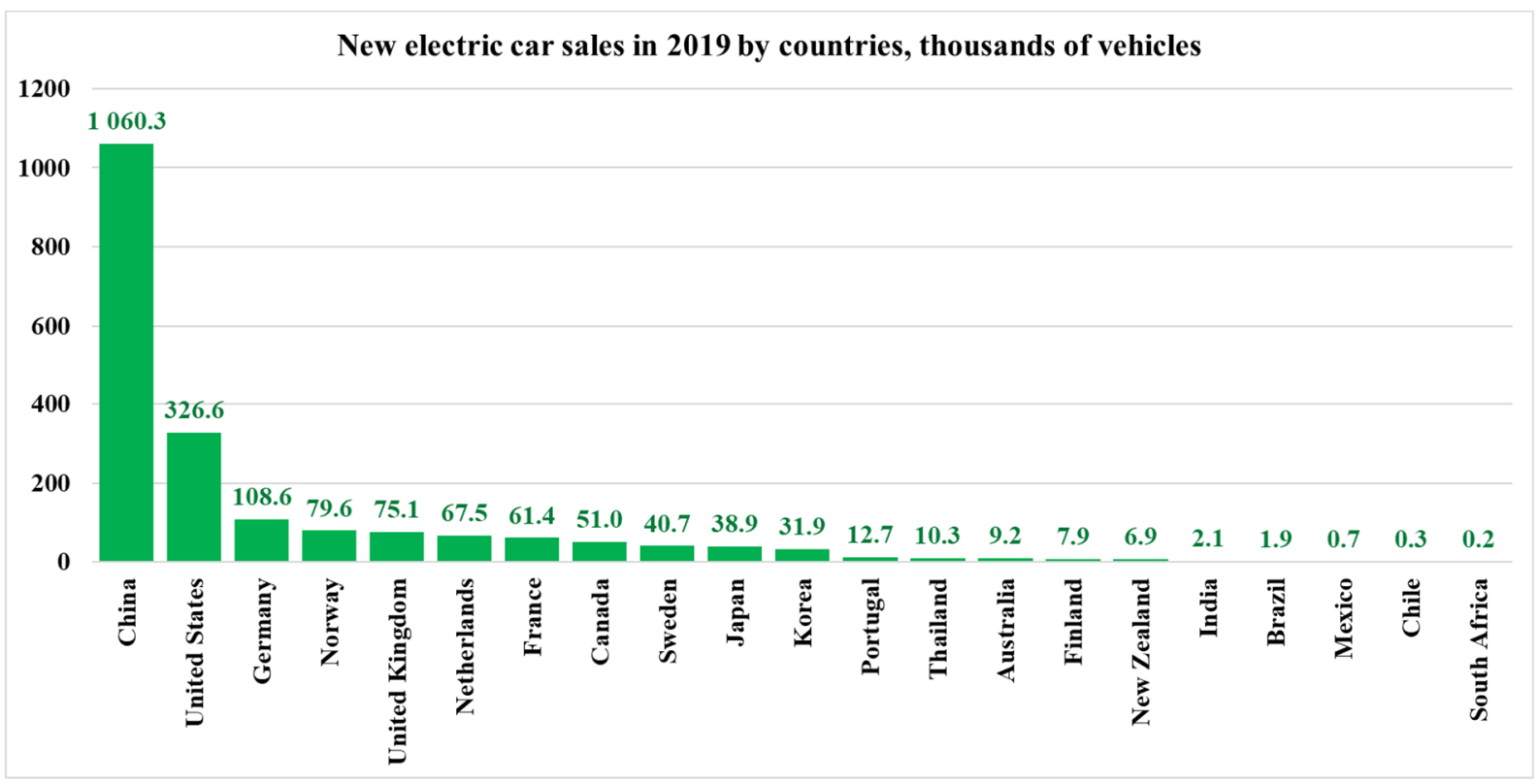

Figure 13. New electric car sales in 2019 by countries, thousands of vehicles [19] (p. 248).

In 2019, more than 65 thousand wind turbines made it possible to avoid 198 million metric tons of carbon dioxide emissions in the US [21]. Today, the most economically feasible is to obtain, with the help of wind generators, not electrical energy of industrial quality, but direct or alternating current (variable frequency), followed by its conversion with the help of heat pumps into heat for heating housing and obtaining hot water. Furthermore, the scheme of the wind generator and control automatics is drastically simplified. A conventional boiler can be used as an energy accumulator for heating and hot water supply. Heat consumption is not so demanding on quality and uninterrupted functioning, so the air temperature in the room can be maintained within a wide range: $19-25^{\circ} \mathrm{C}$, in hot water boilers of $0-97^{\circ} \mathrm{C}$.

White roofs are expected to withstand climate change due to their ability to reflect sunlight. It is obvious that a black roof absorbs the sun's rays and heats up to almost $50{ }^{\circ} \mathrm{C}$ above the ambient temperature. Thus, if it is +40 outside the window, it can be up to +90 degrees on the roof. The temperature of the "cold roof" usually rises by only 5-14 ${ }^{\circ} \mathrm{C}$ compared to the environment. Thus, "cold roofs" improve air quality and prevent smog. Air conditioning costs can be reduced by up to $15 \%$ in the hot season using "cold roofs". A gentle mode of functioning of the roof provides longer life. It was calculated that a 1000 square feet "cold roof" avoids the emission of 20 tons of $\mathrm{CO}_{2}$ carbon dioxide in 20 years [22].

LED lighting is environmentally friendly. Unlike fluorescent lamps, LEDs do not contain mercury, so they are not hazardous waste and do not require special utilization. LED lighting products are almost completely made up of recyclable materials. Low power consumption and high efficiency of LEDs lead to energy savings of up to 80\% [23]. Long LED life reduces lighting fixture changes and reduces waste.

As about $1 / 5$ of heat loss from the house occurs because of poorly insulated windows, replacing old windows with new ones has the effect of reducing heating costs in the cold season and air conditioning in the hot season [24]. The installation of energy-efficient triplepane windows ultimately reduces carbon dioxide emissions, both when using individual 
heating systems and while reducing the consumption of resources from centralized heating systems. In addition to being positive for the environment as a whole, it could have a positive impact on personal finances in the future, if, for example, taxes on carbon dioxide emissions are introduced.

According to the calculations of scientists from the Lawrence Berkeley Laboratory, the operation of consumer electronics in standby mode consumes from 5 to $10 \%$ of all household energy consumption [25]. This leads to approximately $1 \%$ of the world's carbon dioxide emissions into the atmosphere. For example, when a printer finishes printing and goes into sleep mode, power consumption drops, signaling it to disconnect from the mains. Turning off one of the devices does not affect the rest of the extension sockets in any way they continue to work in the mode that the consumer needs.

Mechanical thermostats make it possible to set the temperature, which will remain unchanged until someone manually changes the set parameter. Unlike mechanical thermostats, programmable devices provide more flexibility: the users can program time intervals for different temperatures. If there are no people in the house during the period from 8 am to $6 \mathrm{pm}$, then there is no point in maintaining comfortable temperature conditions during this period. You can lower the temperature, say, to $18{ }^{\circ} \mathrm{C}$, and by the time people arrive, the automation itself will again increase the temperature. This temporary temperature reduction results in additional savings of up to $30 \%$ [26].

Heat pumps are developed to heat and cool buildings utilizing energy transfer from a cooler space to a warmer space (or opposite) applying the refrigeration cycle without external power usage. Heat pumps need less energy than air conditioners. Correctly installed heat pumps are characterized by $300 \%$ efficiency [27].

On average, household appliances, including washing machines, dryers, dishwashers, refrigerators, freezers, air purifiers and humidifiers, will account for $20 \%$ of total home electricity costs. ENERGY STAR devices are helping to reduce this percentage. An ENERGY STAR qualified appliance will consume $10-50 \%$ less energy each year than its inefficient equivalent [28].

It is also should be mentioned that big data collection and analysis, automated management and AI-driven processes can significantly reduce energy consumption.

Thus, many examples of energy-efficient technologies were provided. It is obvious that such technologies save much energy and prevent carbon dioxide emissions. According to the calculations of the authors, energy efficiency can decrease global real energy consumption by $50 \%$.

Although energy-efficient technologies allow using less energy, they also have their disadvantages and limitations. Since energy-efficient technologies are usually new, they are expensive. Implementation of these technologies may take many years, since it is not possible to replace the current machines and industry with the new technologies fast. Some green technologies are still immature, and some are not really green. Therefore, life-cycle assessments are undertaken and studies on the overall energy harvest are on the way [29-33]. Some of the technologies, for example, solar panels and wind turbines, are dependent on weather conditions, and cannot be used everywhere. Therefore studies on spatial and temporal distribution of solar and wind potentials are currently being undertaken [34-40].

\subsection{Renewable Energy}

Renewable energy is energy that is produced using renewable sources including sun, wind, water, geothermal heat and other sources. It is known that historically, only renewable energy was available for people until much cheaper energy sources, including coal, oil and gas, replaced renewable energy sources, causing a large number of environmental disasters and global warming [41]. The temperature of the Earth's atmosphere has increased quicker from 1970 than in any other half-century period during the last 2000 years or more [42]. Now, when global surface temperature has already increased by more than $1^{\circ} \mathrm{C}$ compared to the pre-industrial level, mankind is in search of ways to stop 
global warming and not to permit new disasters. Dolf Gielen et al. demonstrated in [6] that energy efficiency and renewable energy could become the solution to the problem. The share of renewable energy in the total primary energy supply already exceeded $15 \%$. According to Dolf Gielen et al. [6], if we apply electrification of end-uses, energy efficiency technologies and renewable energy together, we can reduce emissions by up to $94 \%$. Dolf Gielen et al. suppose that the share of renewable energy in the total primary energy supply can reach up to $63 \%$ in 2050 [6]. BP assumes that by 2050 the share of renewable energy in primary energy consumption can reach $44 \%$ in the Rapid scenario and $60 \%$ in the Net Zero scenario [4]. IRENA, in [43], describes a Transforming Energy Scenario in which the share of renewable energy in energy demand will exceed $65 \%$ by 2050 .

Renewable energy is practically endless, and requires lower maintenance. Renewable energy can also save money. We already talked about the benefits of using solar panels and wind turbines in the paragraph above. The advantage that can be considered as the main advantage is that the renewable energy generation process almost does not contaminate the air and water. Renewable energy reduces carbon dioxide and decentralizes power generation [43]. However, renewable energy depends on the climate and geographical zone, requires energy storage and has a high cost. The amount of power generated using renewable energy technology is still small, due to the deplorably still unprofessional management of its volatility. Besides that, solar panels, for example, require a lot of space to install [44], which, however, is possible - especially in large countries [45]. A long time is needed for renewable energy to become reliable and be used everywhere, and therefore this highly needed task must be most quickly started in every country now.

\subsection{Hydrogen}

Today, hydrogen is already used at an industrial scale across the world. It is mostly needed in industry-it is used for the production of ammonia and methanol, refining and treating metals, including steel, in the oil refining process, in food processing and for NASA space programs [46]. Many power plants produce electricity using hydrogen in fuel cells. Hydrogen fuel cells are also installed in cars. Furthermore, hydrogen can be used for heating buildings. Baxi, Viessmann and Worcester Bosch already have prototypes, and test $100 \%$ hydrogen-ready boilers [47] (now these boilers are compatible with natural gas). In 2018, Viessmann introduced a highly efficient cutting-edge heating device (Vitovalor PT2, Viessmann, Allendorf, Germany) that provides hot water and heating, applying advanced fuel cell technology to convert hydrogen into energy [48]. Hydrogen is useful in power generation; it allows to store renewable energy. Along with ammonia, it helps gas turbines to improve their power system flexibility.

Global demand for pure hydrogen shown in Figure 14 has been increasing in the last few decades.

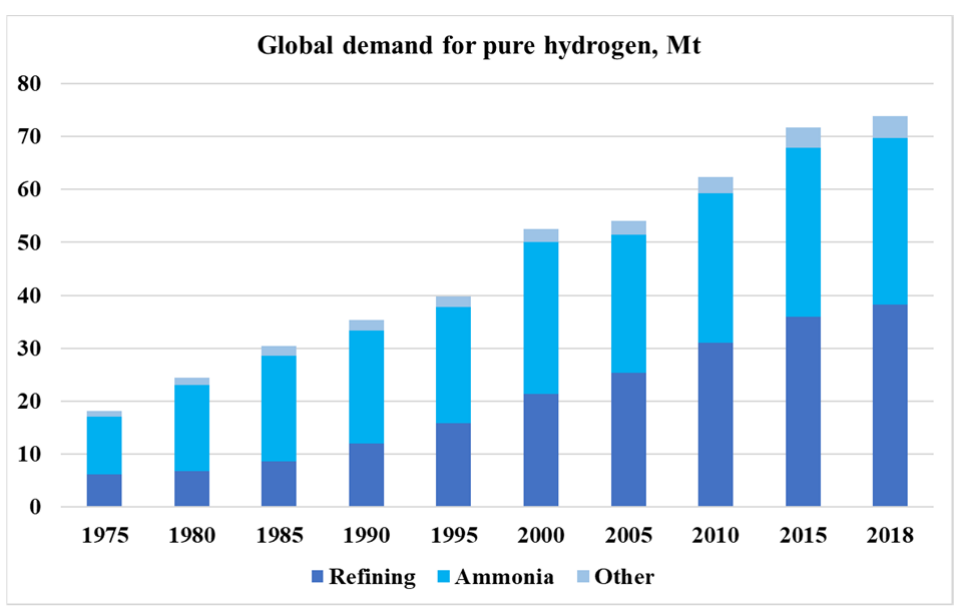

Figure 14. Global demand for pure hydrogen, Mt, 1975-2018 [49]. 
Hydrogen $\left(\mathrm{H}_{2}\right)$ itself is not available on Earth and should be produced. Electrolysis and steam-methane reforming are the main ways to extract hydrogen from a variety of sources [50]. Electrolysis allows separating the oxygen from hydrogen atoms by passing a high current of electricity through water. Today there are two main disadvantages of this technology: it is expensive, and it burns fossil fuels.

$95 \%$ of hydrogen is produced by the steam-methane reforming process, in which carbon and hydrogen are separated in methane [51]. This method also suggests greenhouse gases emission that contributes to global warming.

Today, approximately 120 million tons (14.4 exajoules) of hydrogen are produced annually [52]. Two-thirds of this is pure hydrogen, and the remaining part is a mixture with other gases.

Increasing interest in hydrogen is explained by its advantages. Hydrogen can be produced from different sources, including biomass, coal, gasoline, methane, water and so on. Today, approximately $95 \%$ of all hydrogen is generated from natural gas and coal [53]. Hydrogen carries energy. Hydrogen can store energy, and if produced from a renewable energy source (then called green hydrogen), it can be considered equivalent to renewable energy - however, if produced from fossil energy, this non-green hydrogen must be considered as fossil fuel, as its creation emitted $\mathrm{CO}_{2}$, even if $\mathrm{H}_{2}$ at the time of its combusting has a small environmental impact. Hydrogen energy is very efficient. Hydrogen can provide a sustainable production system (in the case of using electrolyzers powered by renewable energy).

Hydrogen also has disadvantages. Hydrogen extraction is very expensive, using both electrolysis and steam reforming. Although hydrogen is a renewable source, its extraction today is not environmentally friendly; it requires fossil fuels and produces emissions. As hydrogen has a low volumetric energy density, it should be compressed to a liquid state for storage, which is difficult. Hydrogen can be dangerous because it is highly flammable and has a volatile substance. There always is a risk of exploding a hydrogen station. Hydrogen is not able to perform well in some conditions and temperatures.

Although hydrogen is widely used today, it is far away from reaching its full potential as an energy source. Still, many research is required to provide cheap and sustainable green hydrogen energy from renewable energy sources only (via hydropower, solar panels or wind farms) without producing emissions, or at least using carbon capture storage (CSS) systems that help to avoid carbon from being released. Another problem is that today, there is no ready infrastructure for hydrogen energy usage. For example, vehicles and service stations should be significantly changed to conform to hydrogen requirements.

It should be mentioned that hydrogen can be grey, blue or green, depending on how it is produced. Grey hydrogen is the least environmentally friendly hydrogen. It is obtained from fossil fuels - mostly by dividing natural gas into hydrogen and carbon dioxide. It was calculated that from $1 \mathrm{~kg}$ of produced grey hydrogen, approximately $10 \mathrm{~kg}$ of carbon dioxide are emitted into the atmosphere [54]. Unfortunately, now a major part of the produced hydrogen is grey hydrogen. When blue hydrogen is produced, natural gas is also divided into hydrogen and carbon dioxide. Carbon dioxide is then can be captured and stored, but it is very expensive and highly unusual under present circumstances. Another problem is that the storage reservoirs are limited. This makes it impossible to widely use blue hydrogen. The hydrogen can also be green. It is produced through the above-mentioned electrolysis of water when electricity is generated by zero-carbon sources only. This technology allows reducing $\mathrm{CO}_{2}$ emissions, but it is still very expensive. In 2015, the cost of production of $1 \mathrm{~kg}$ of green hydrogen was $\$ 6$ [55]. During the last five years, the green hydrogen production cost has been reduced to $\$ 3$ per kilogram, going by information of the European Commission's July 2020 hydrogen strategy [56]. For comparison, $1 \mathrm{~kg}$ of produced grey hydrogen costs $\$ 1.80$, while blue hydrogen costs $\$ 2.40$. The United States Department of Energy expects that in 2025, the green hydrogen production cost will be reduced to $\$ 2$ per kilogram, and in this case, green hydrogen can become competitive against other non-renewable sources [53]. 
The European Union, Canada, South Korea, Australia, the Netherlands, Norway, Chile and other countries have already developed their hydrogen strategies. European Union's strategy focuses on hydrogen produced from renewable energy sources. The strategy consists of three stages. Stage one supposes that electrolyzers' capacity will be increased up to 6 GW by 2024. Stage two aims to increase electrolyzers' capacity up to 40 GW by 2030. EU also plans to produce up to 10 million tons of renewable hydrogen per year by 2030 [57]. For the third stage (after 2030), large-scale renewable hydrogen production is planned.

Canada's Hydrogen Strategy, released on December 16, 2020, includes a plan of significant clean hydrogen production, and also analyzes a way of achieving a net-zero emissions scenario by 2050 . Before 2025, the infrastructure and foundations for the hydrogen economy should be prepared. The years 2025-2030 aim to make the hydrogen sector diverse, and stimulate its growth. After 2030, the sector is supposed to expand. Canada targets to provide up to $30 \%$ of end-use energy using hydrogen, which will be the top global clean low-carbon hydrogen [58]. A hydrogen export is also planned.

The National Green Hydrogen Strategy of Chile was rolled out in November 2020. By 2025, it aims to produce 5 GW using electrolysis capacity, and by 2030, to develop the cheapest green hydrogen in the world [59].

South Korea set a target to produce 6.2 million fuel cell electric vehicles powered by hydrogen that do not produce harmful emissions, and open 1200 refilling stations by 2040. Furthermore, $15 \mathrm{GW}$ of fuel cells in South Korea will be supplied for power generation.

Since in Australia, renewable energy became cheaper than electricity generated by new coal-fired and gas-fired power stations, it is planned that the "hydrogen valley", that will be constructed in New South Wales, will substitute its current coal industry [60].

BP supposes that hydrogen use may reach up to $60 \mathrm{EJ}$ by 2050 [61]. The share of green hydrogen in the structure of the world fuel and energy balance for the 21st century calculated by authors is presented in Figure 15. The curve was calculated using a logistic function, the parameters of which were identified based on current statistics and BP's forecast of hydrogen use [61]. Furthermore, to construct this logistic function, the following facts and projections were used. Today, the share of green hydrogen is less than $1 \%$ of the total hydrogen produced. In the next decades, an exponential increase (up to $60 \%$ per year) of green hydrogen production is expected [62]. By 2050, green hydrogen production may reach up to 150-200 million metric tons according to the Transforming Energy Scenario described in $[63,64]$. More optimistic green hydrogen demand projections of 500 million tons per year also exist [65]. In general, most reports suggest that hydrogen produced from renewable energy sources only will account for $10-25 \%$ of power consumption in the 21 st century [66-68].

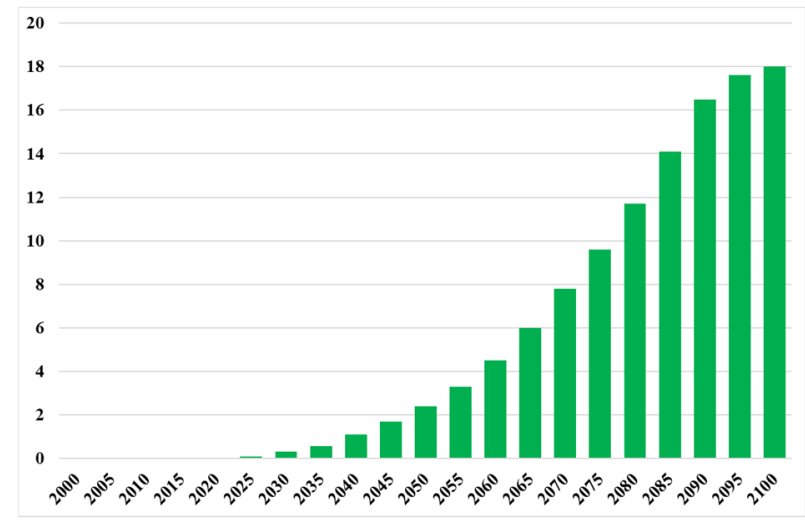

Figure 15. The share of green hydrogen (\%) in the structure of the world fuel and energy balance for the 21st century (ambitious scenario) (calculated by authors).

It is important to again notice that the hydrogen that authors mention and use in their calculations is green hydrogen produced using renewable energy sources only, unlike grey and blue hydrogen that can be obtained using coal or natural gas. 


\section{Mathematical Description}

\subsection{Methodology}

To find a combination of parameters that allow maintaining the temperature below $2{ }^{\circ} \mathrm{C}$ compared to the pre-industrial level, the tool developed by authors and described in [69] was used.

The key features and assumptions of this mathematical tool are the following [69]. The average global per capita energy consumption $e_{w}$ will stabilize at the level of 1.8 toe (tonnes of oil equivalent) per year in the 21st century. Thus, the nominal global energy demand $E_{w}$ in the year $t$ will change in direct proportion to the global population $N_{w}(t)$ :

$$
E_{w}(t)=e_{w} \cdot N_{w}(t)
$$

Several scenarios of the world's population are considered:

- $\quad 7.4$ billion people by the year 2100 (using the model with lags described in [70]);

- 9.3 billion people by the year 2100 (using the model with lags [70]);

- 10 billion people by the year 2100 (using the model of sustainable evolutionary growth according to Kapitsa [71]); and

- 11 billion people by the year 2100 (according to the UN scenario [72]).

The population development scenarios are presented in Figure 16.

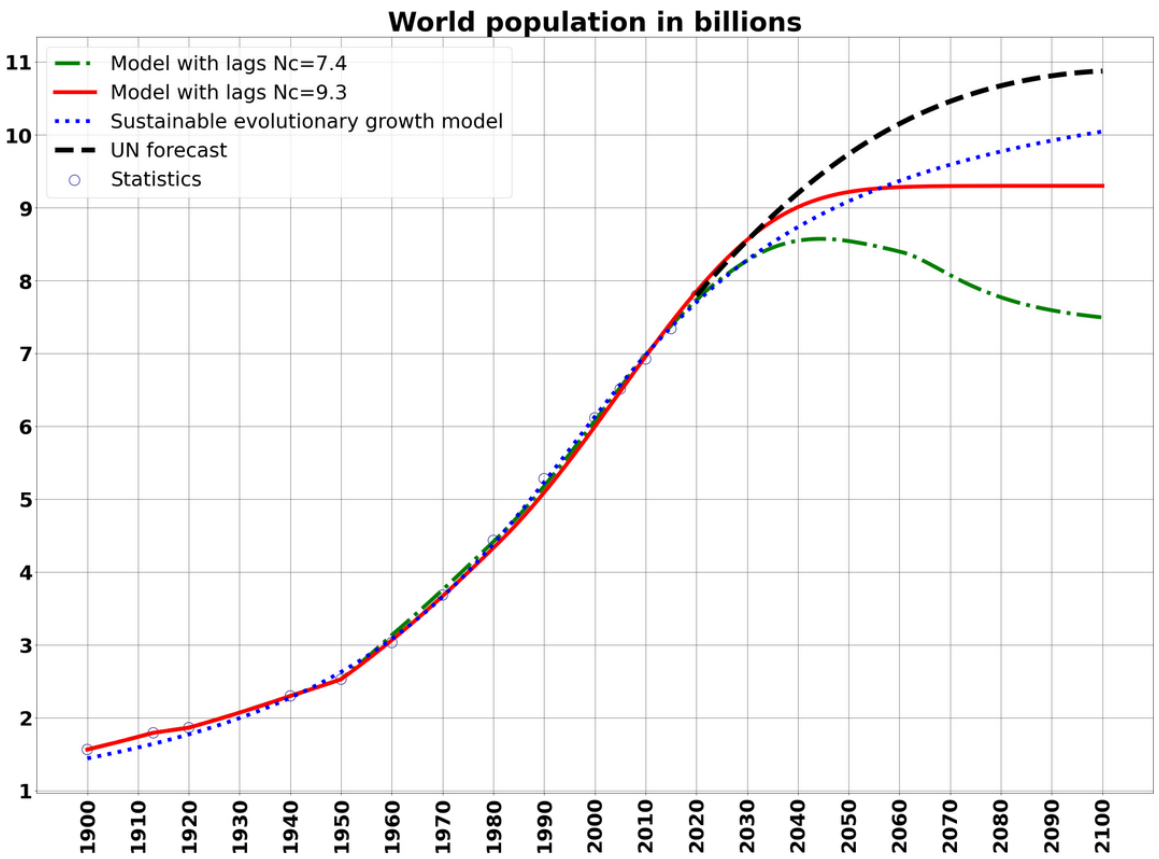

Figure 16. Scenarios of the world's population in the 21st century.

The real global energy consumption is calculated using the obtained nominal global energy consumption and energy efficiency coefficient, introduced by Plakitkin [73] (shown in Figure 17), which reflects the level of technological development of power engineering. This coefficient works for developed countries as well as for developing countries (with a time lag). Plakitkin calculated that in 1900 the coefficient was 0.1 (or 10\%), and projected that it will be 0.5 in 2050 and 0.9 in 2200 . Using statistical data and projected points, Plakitkin created and verified a model described by the logistic curve allowing to calculate energy efficiency coefficient for every year of the 21st century. Energy-efficient solutions that were described above can significantly decrease energy consumption growth. The performed calculations show that real world energy consumption can be decreased by up to $50 \%$, compared to the nominal energy consumption. 


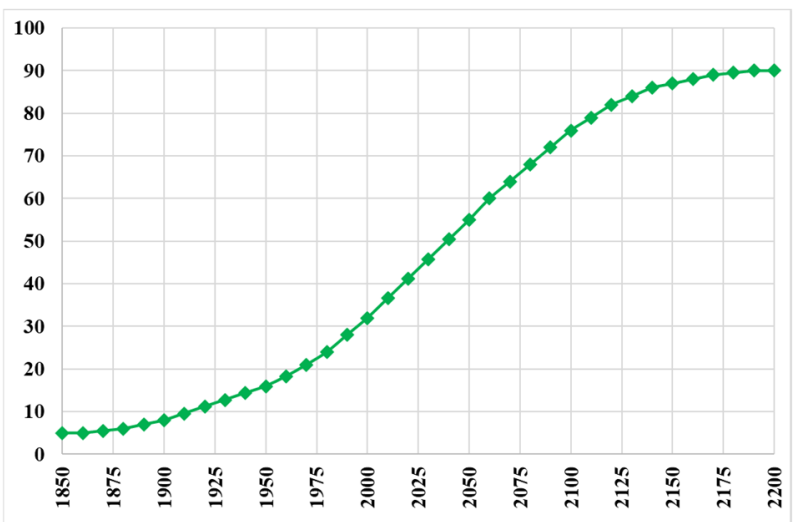

Figure 17. Energy use coefficient (percentage).

The dynamics of real global energy consumption in the 21st century are presented in Figure 18.

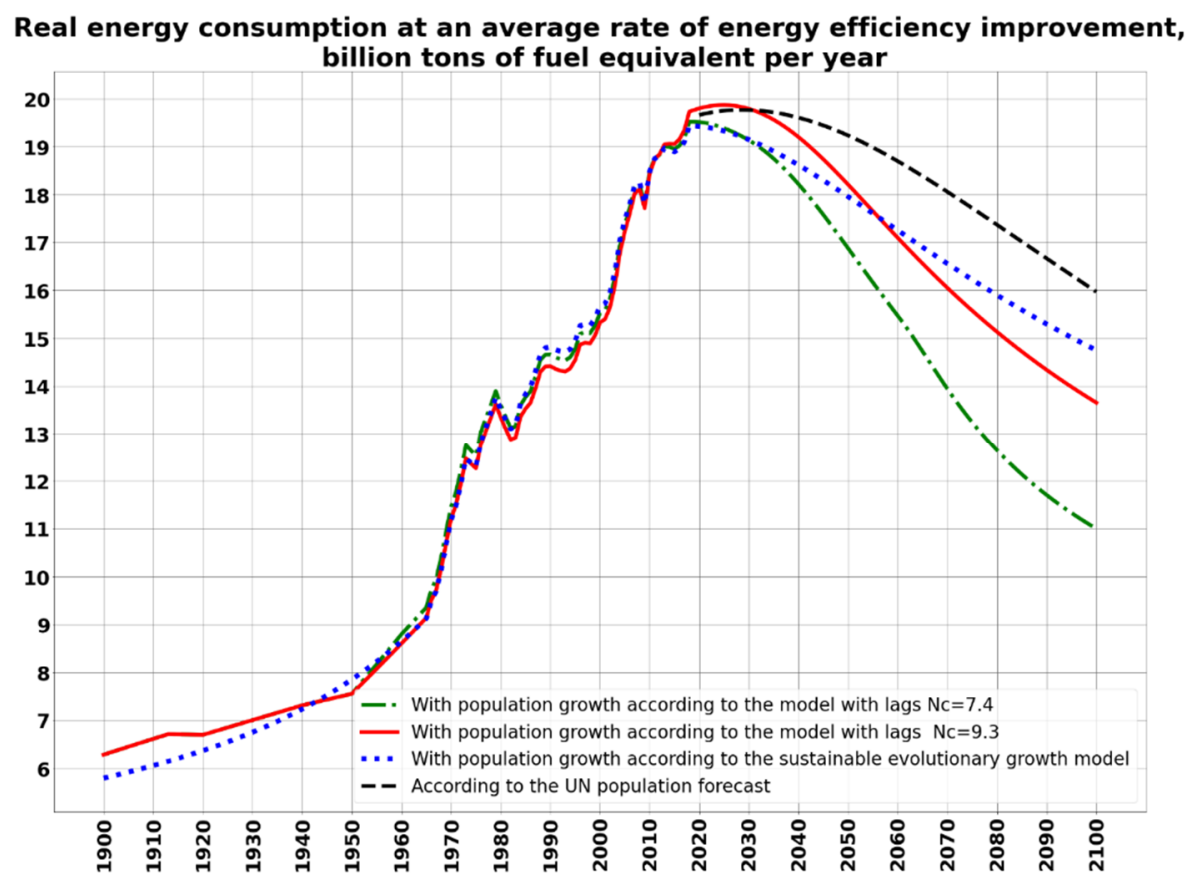

Figure 18. Dynamics of real global energy consumption in the 21st century.

Two scenarios of changes in the structure of the world fuel and energy balance for the 21 st century (conservative and ambitious) are calculated. The conservative scenario is based on the idea that technologies, social behavior and government policies will not change, and stay at the level of the recent past. The ambitious scenario assumes significant changes in energy efficiency and the structure of the world fuel and energy balance (including increased hydrogen share) and CCS technologies usage.

The value of the global capacity of different energy sources are calculated using an approximating logistic function of the form [74]

$$
E_{r}(t)=E_{r 1}+\frac{E_{r 2}}{1+r_{E S} \cdot \exp \left[-\vartheta_{E S}\left(t-T_{0}\right)\right]}
$$

where $E_{r}(t)$ is the projected growth of energy capacity of a resource; $E_{r 1}, E_{r 2}, r_{E S}, \vartheta_{E S}$ are constant parameters to be identified. The parameters are calculated using the least squares method, based on statistical data for years from 2000 to 2019 and scenario values for solar and wind power plants presented in the IRENA report [75]. The dynamics of changes 
in the structure of the world fuel and energy balance for the 21st century are shown in Figures 19 and 20.

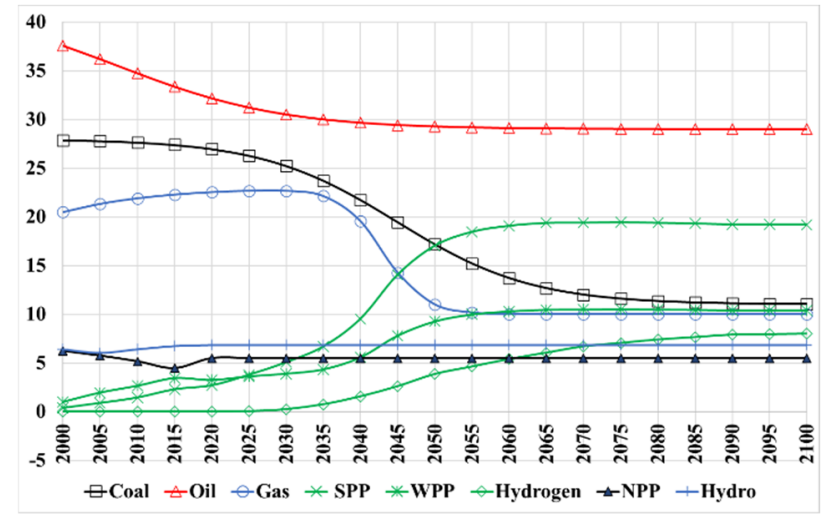

Figure 19. The dynamics of changes in the structure of the world fuel and energy balance (shares in energy consumption) for the 21st century (conservative scenario) (for Coal, Oil, Gas, Solar Power Plants (SPP), Wind Power Plants (WPP), Hydrogen, Nuclear Power Plants (NPP) and Hydro energy).

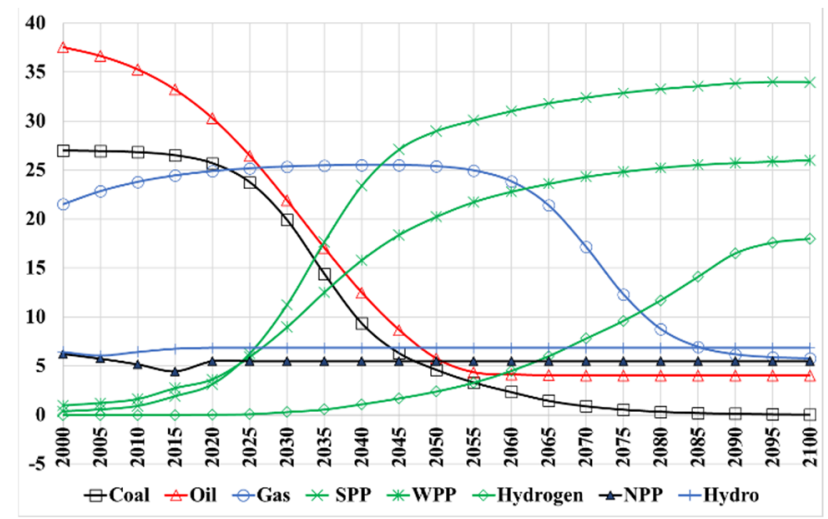

Figure 20. The dynamics of changes in the structure of the world fuel and energy balance (shares in energy consumption) for the 21st century (ambitious scenario) (for Coal, Oil, Gas, Solar Power Plants (SPP), Wind Power Plants (WPP), Hydrogen, Nuclear Power Plants (NPP) and Hydro energy).

Based on outlooks of energy agencies $[4,5,46,52,75-78]$, we assume that the share of hydro energy in the world fuel balance will be constant $(7 \%)$, and the share of bioenergy will increase up to $8.5 \%$.

Adding coal, oil and gas we obtain the value of consumption of fossil hydrocarbon fuels $E_{w f f}(t)$.

The next step is to calculate the values of anthropogenic carbon dioxide emissions. For this purpose, the global average carbon intensity coefficient $c_{c}(t)$, is determined using the Marland-Rotti equation [79]

$$
c_{\mathcal{c}}=\frac{0733 E_{s}+0,586 E_{j}+0,398 E_{g}}{E_{\mathcal{c}}}
$$

where $E_{c}$ is the total volume of consumption of hydrocarbon fuels; and $E_{s}, E_{j}, E_{g}$ are the consumption of solid (coal), liquid (oil) and gaseous (natural gas) fuels (in tfe).

To calculate the values of anthropogenic carbon dioxide emissions, the average carbon intensity coefficient $c_{\mathcal{c}}(t)$ is multiplied by the value of consumption of fossil hydrocarbon fuels $E_{w f f}(t)$ :

$$
C_{w}(t)=c_{c} \cdot E_{w f f}(t)
$$




\subsection{Results}

The results of the calculations are shown in Figures 21 and 22.

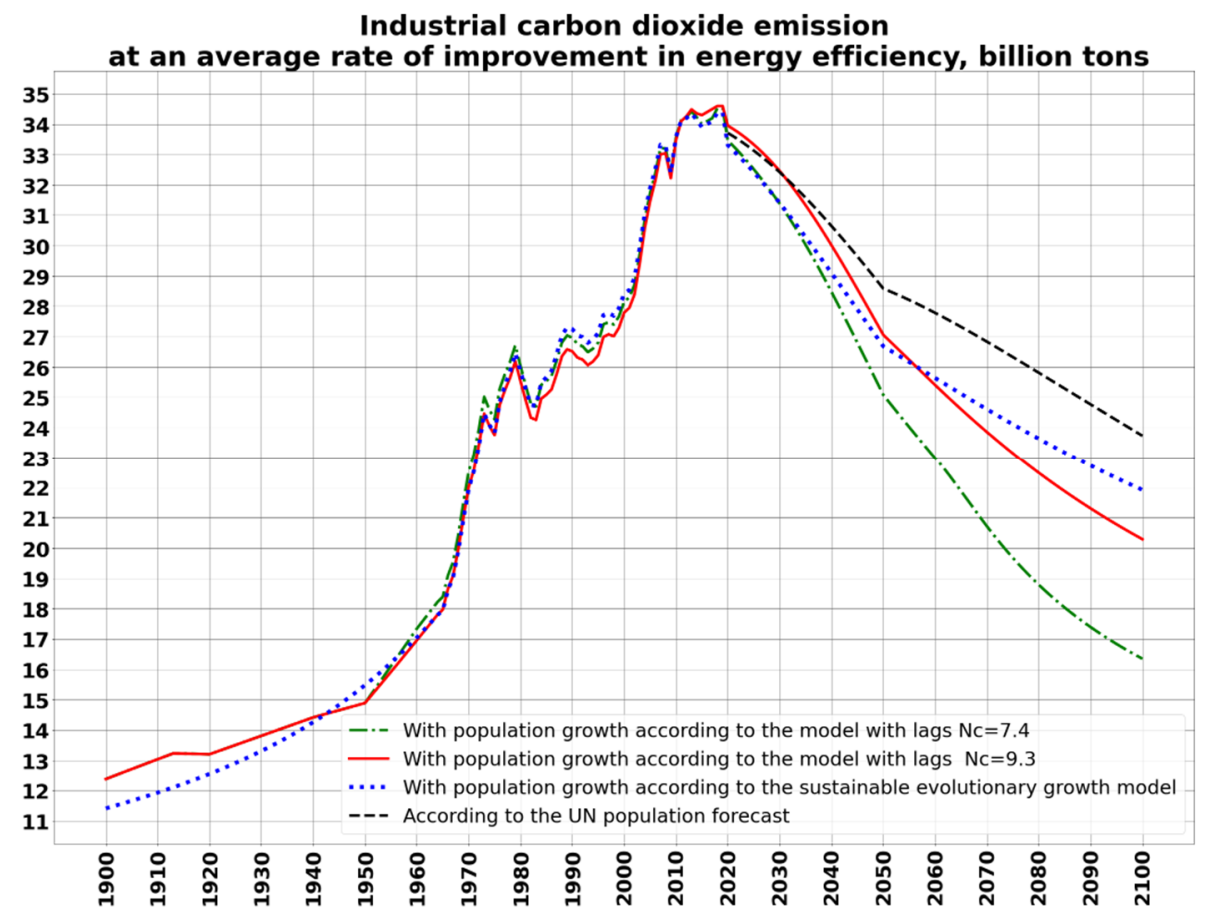

Figure 21. Dynamics of reduction of anthropogenic emissions of carbon dioxide $\left(\mathrm{CO}_{2}\right)$ into the atmosphere in the 21st century under the conservative scenario of the energy transition.

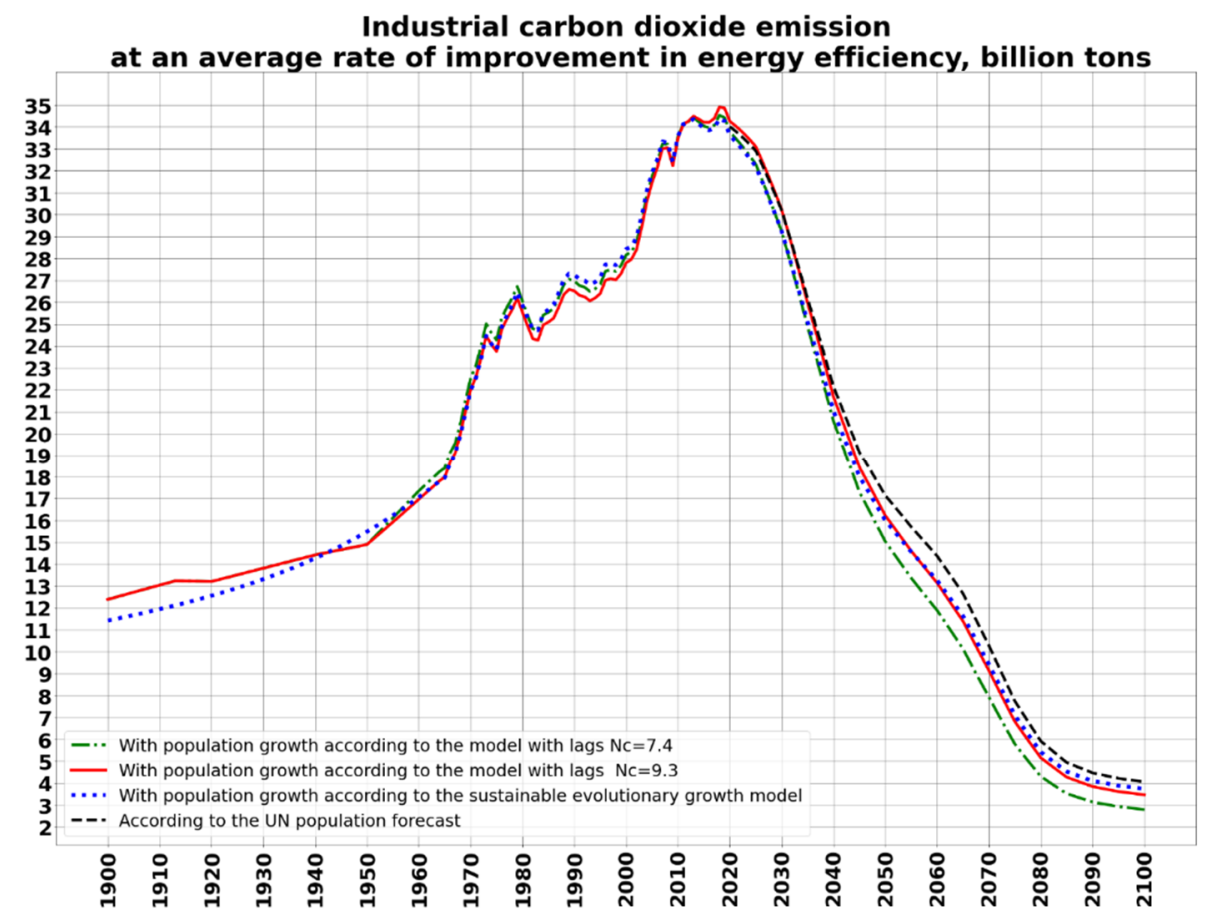

Figure 22. Dynamics of reduction of industrial $\mathrm{CO}_{2}$ emissions into the atmosphere under the ambitious energy transition scenario using CCS technology.

It should be mentioned that the ambitious scenario also assumes CCS technology usage. In the "Blue Map" scenario [80], it is shown that if we start to develop and widely use CCS technologies now, $\mathrm{CO}_{2}$ emissions can be decreased by $19 \%$ by 2050 . The detailed 
mathematical description of the CCS technology usage was described by authors in [69]. Every year, 26 CCS facilities capture approximately $40 \mathrm{Mt}$ of carbon dioxide [81]. However, it is important to notice that CCS technology has limitations. Not all power plants have the required equipment for CCS installation. It was calculated that one billion US dollars would be needed to prepare one plant for CSS, which is very expensive and cannot be used everywhere [82]. It is obvious that not every country in the world will have sufficient $\mathrm{CO}_{2}$ storage capacity [83]. Furthermore, the risk of leakages and environmental contamination exists. All these limitations were taken into consideration.

As soon as the emissions of carbon dioxide $\left(\mathrm{CO}_{2}\right)$ into the Earth's atmosphere $C_{w}$ are calculated (using Formulas (1)-(4)), it is possible to obtain carbon accumulation $C_{\Sigma}(T)$ in the Earth's atmosphere in the 21st century using the formula

$$
C_{\Sigma}(T)=\int_{T_{0}}^{T} C_{w}(t) d t-3,1\left(T-T_{0}\right)
$$

where $T_{0}=2020 ; 2020 \leq T \leq 2100$ (see Figure 23).

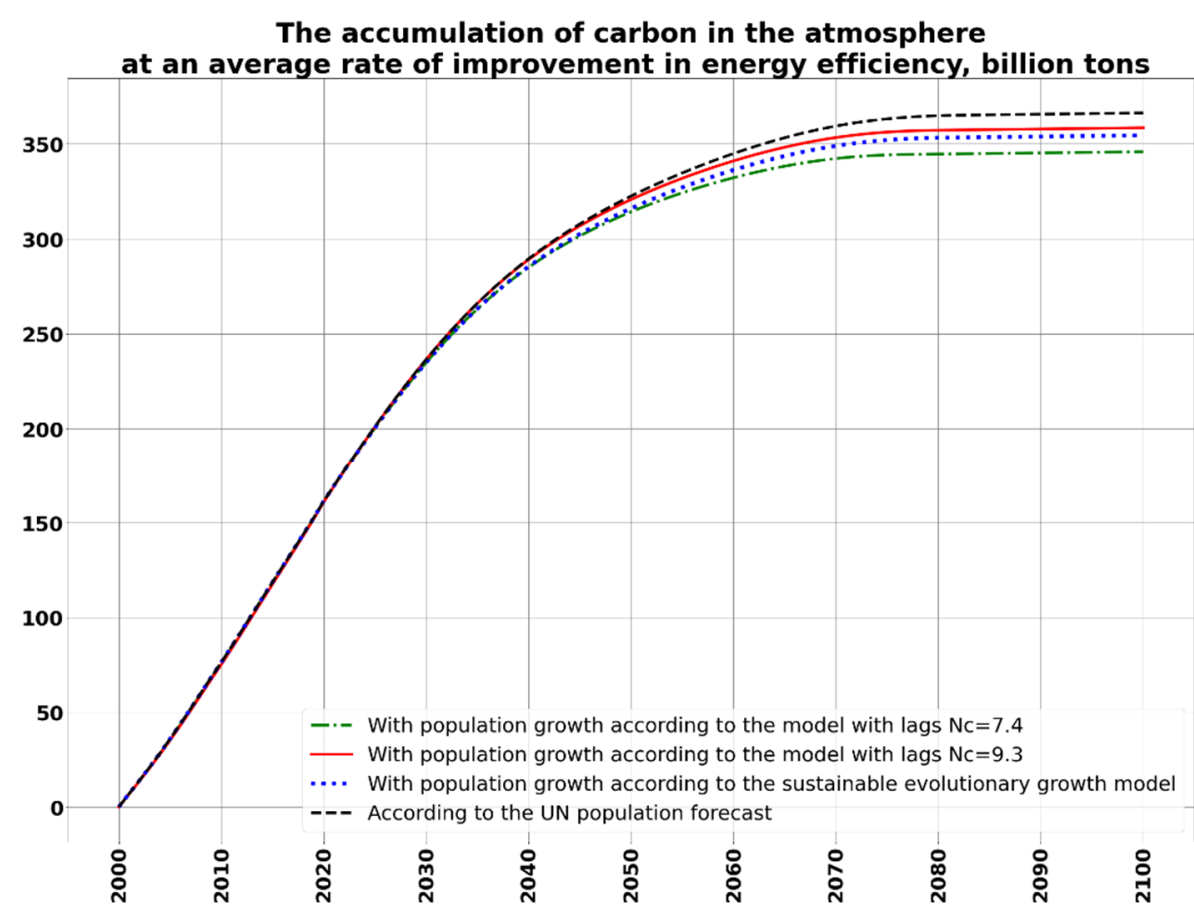

Figure 23. Dynamics of carbon accumulation in the Earth's atmosphere in the 21st century under the ambitious scenario of energy transition using CCS technology.

Terrestrial ecosystems and oceans absorb some part of the carbon. A. Tarko estimates this part as 3.1 Gt per year [84] (p. 177).

To estimate the deviation of the average global temperature, Tarko suggested the following formula [84]

$$
T_{g}=\left\{\begin{array}{cc}
2,5\{1-\exp [-0,82(z-1)]\}, & z \geq 1 \\
-5,25 z^{2}+12,55 z-7,3, & z<1
\end{array}\right.
$$

where $T_{g}$ is the deviation of the global average temperature of the atmosphere from the present value $\left(+15^{\circ} \mathrm{C}\right)$, due only to the greenhouse effect caused by anthropogenic carbon dioxide emissions.

$$
\begin{aligned}
& z=1+\frac{C_{\Sigma}}{C_{0}} \\
& C_{0}=867 G t .
\end{aligned}
$$


As known, in 2018 the global warming has already raised to $1{ }^{\circ} \mathrm{C}$ compared to the pre-industrial temperature of $+14{ }^{\circ} \mathrm{C}$. Thus, the conservative scenario will keep global warming in the 21st century, at the level of $2{ }^{\circ} \mathrm{C}$ (see Figure 24).

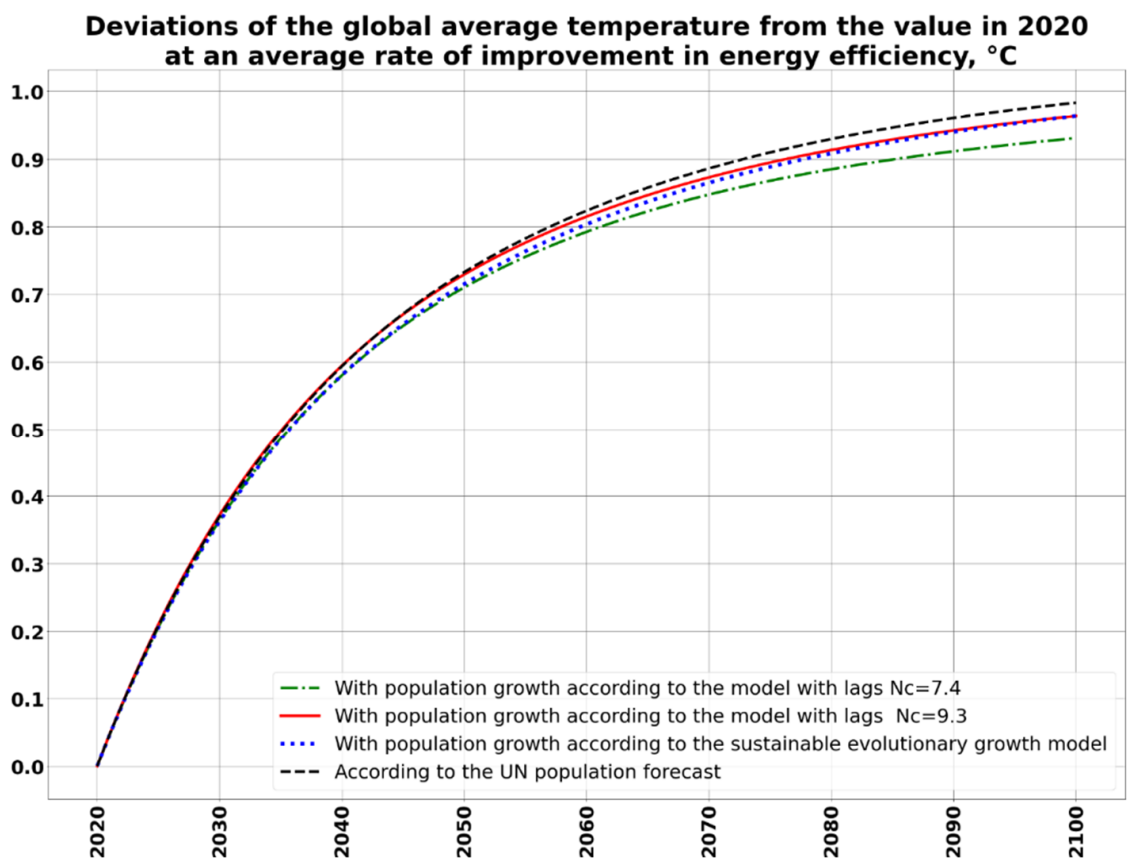

Figure 24. Dynamics of the deviation of the average global temperature of the surface atmosphere in the 21st century under the implementation of the conservative scenario of the energy transition, as well as the application of CCS technology in coal power engineering.

The ambitious scenario will keep global warming in the 21st century at the level of $1.7^{\circ} \mathrm{C}$ (see Figure 25).

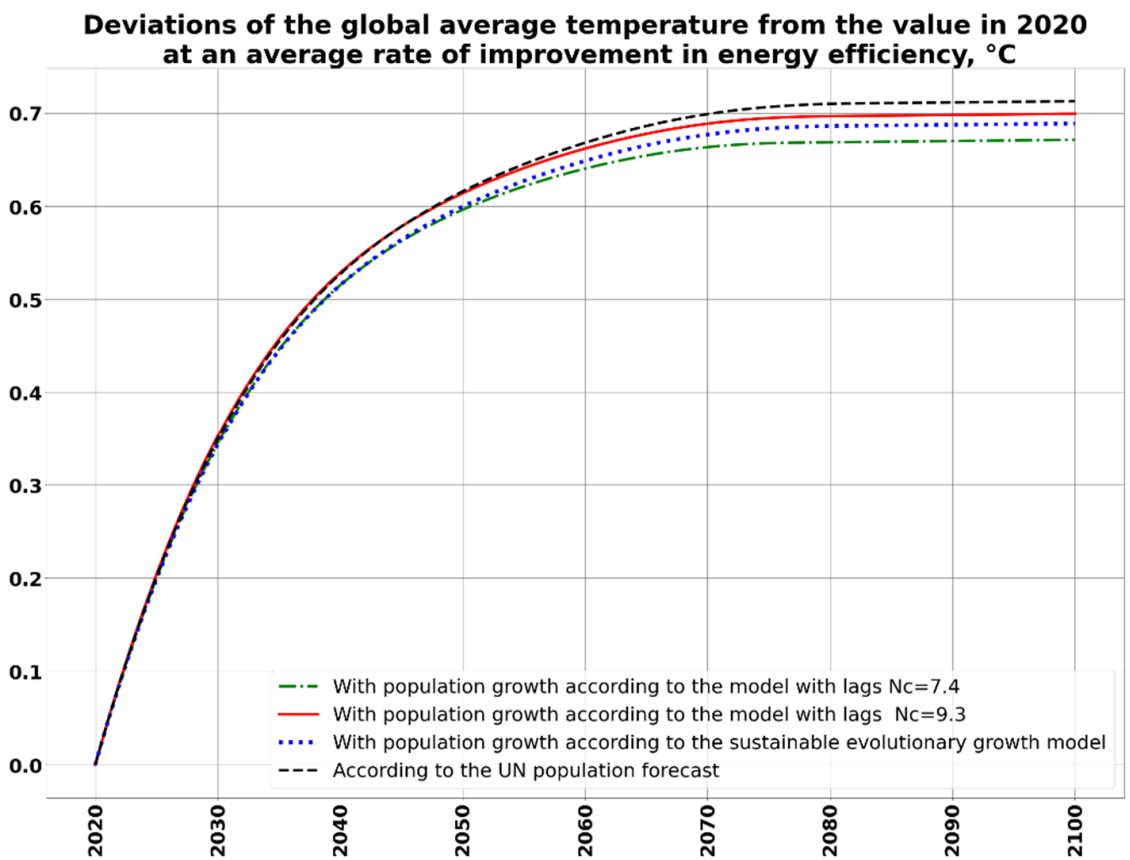

Figure 25. Dynamics of the deviation of the average global temperature of the surface atmosphere in the 21st century in the implementation of the ambitious scenario of the Great Energy Transition, as well as the application of CCS technologies in coal energy. 


\section{Conclusions}

In this work, modern trends and problems of the energy sector were discussed. The structure of the world fuel and energy balance was studied and calculated for the 21st century. Furthermore, a detailed explanation of energy-efficient technologies was given. Green hydrogen, as a temporary and possibly clean energy carrier, was also analyzed.

The large volume of statistical data describing historical and latest trends in the energy sector made it possible to develop and verify the tool that allows estimating the deviation of the average global temperature of the surface atmosphere from pre-industrial levels in the 21st century. To perform calculations, all the parameters of the tool were identified using the least squares method. The algorithm includes the following steps:

- calculation of various scenarios of growth in the population of the world;

- calculation of the corresponding scenarios for the development of the dynamics of energy demand, based on the new paradigm of energy consumption;

- $\quad$ scenarios writing for the dynamics of the structure of energy consumption by types of energy sources (coal, oil, gas, renewable energy sources, nuclear energy, hydropower);

- $\quad$ scenarios writing for the dynamics of demand for organic fossil fuels (coal, oil, gas);

- $\quad$ scenarios writing for the dynamics of changes in the structure of hydrocarbon energy sources (coal, oil, gas);

- calculation of the dynamics of $\mathrm{CO}_{2}$ emissions into the atmosphere during the combustion of hydrocarbon fuels, taking into account structural changes in the consumption of organic fossil fuels (coal, oil, gas), as well as the use of technologies for carbon capture and storage (CCS);

- calculation of the dynamics of $\mathrm{CO}_{2}$ accumulation in the atmosphere, taking into account non-industrial $\mathrm{CO}_{2}$ emissions (due to deforestation and soil erosion) and absorption of part of the emissions by oceans and terrestrial ecosystems; and

- calculation of changes in the global average temperature of the surface atmosphere.

Calculations showed that the conservative scenario is only able to keep global warming at a level of $2{ }^{\circ} \mathrm{C}$ compared to the pre-industrial level.

Using big data and the developed tool authors could find a scenario that allows keeping global warming at the level of $1.7^{\circ} \mathrm{C}$. It became possible due to the usage of:

- renewable energy;

- $\quad$ energy-efficient technologies;

- CCS technology; and

- green hydrogen.

Since the developed tool makes it possible to calculate different scenarios and find appropriate parameters for these scenarios, in the future, the tool will be used for search of a scenario that will allow keeping global warming at the level of $1.5^{\circ} \mathrm{C}$, which is the ambitious goal of the Paris agreement. Furthermore, the authors plan to perform a detailed study of CCS technology, and make calculations for different countries of the world.

Author Contributions: Data curation, O.I.D.; writing—original draft preparation, A.A.A. All authors have read and agreed to the published version of the manuscript.

Funding: This work was supported by a grant from the Russian Science Foundation No. 20-6146004 for the project "World development and the limits of growth in the 21st century: modeling and forecasting".

Institutional Review Board Statement: Not applicable.

Informed Consent Statement: Not applicable.

Data Availability Statement: There are no publicly archived datasets generated during the study.

Conflicts of Interest: The authors declare no conflict of interest. 


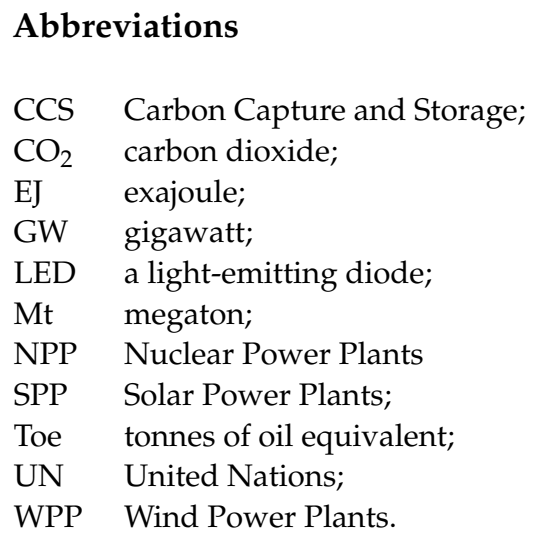

\section{References}

1. Tebor, C. The current drought is worldwide. Here's how different places are fighting it. Los Angeles Times. 16 July 2021. Available online: https:/ / www.latimes.com/world-nation/story/2021-07-16/drought-water-use-strategies (accessed on 23 August 2021).

2. Dixon, R. Siberia's wildfires are bigger than all the world's other blazes combined. The Washington Post. 11 August 2021. Available online: https:/ / www.washingtonpost.com/world/2021/08/11/siberia-fires-russia-climate/ (accessed on 15 August 2021).

3. Pasch, R.J.; Penny, A.B.; Berg, R. Hurricane Maria; National Hurricane Center: Miami, FL, USA, 2019.

4. Energy Outlook 2020. Available online: https://www.bp.com/content/dam/bp/business-sites/en/global/corporate/pdfs/ energy-economics/energy-outlook/bp-energy-outlook-2020.pdf (accessed on 7 August 2021).

5. Statistical Review of World Energy; British Petroleum Co.: London, UK, 2021. Available online: https://www.bp.com/en/global/ corporate/energy-economics/statistical-review-of-world-energy.html (accessed on 20 July 2021).

6. Gielen, D.; Boshell, F.; Saygin, D.; Bazilian, M.D.; Wagner, N.; Gorini, R. The role of renewable energy in the global energy transformation. Energy Strat. Rev. 2019, 24, 38-50. [CrossRef]

7. Carbon Capture. Available online: https://www.c2es.org/content/carbon-capture/ (accessed on 12 August 2021).

8. Bagher, A.M.; Vahid, M.M.; Mohsen, M.; Parvin, D. Hydroelectric energy advantages and disadvantages. Am. J. Energy Sci. 2015, 2, 17-20.

9. Denisov, S.E.; Denisova, M.V. Analysis of hydropower potential and the prospects of developing hydropower engineering in south ural of the Russian Federation. Procedia Eng. 2017, 206, 881-885. [CrossRef]

10. Gatte, M.T.; Rasim, A.K. Hydro power. Energy Conserv. 2012, 9, 95-124.

11. Global CO2 Emissions by Sector; IEA: Paris, France, 2019. Available online: https://www.iea.org/data-and-statistics/charts/ global-co2-emissions-by-sector-2019 (accessed on 19 October 2021).

12. Global Electric Vehicle Outlook Report; IEA: Paris, France, 2021. Available online: https://www.iea.org/reports/global-ev-outlook2021 (accessed on 13 August 2021).

13. Global Status of CCS Report; Global CCS Institute: Melbourne, Australia, 2020. Available online: https://www.globalccsinstitute. $\mathrm{com} /$ resources/global-status-report/ (accessed on 5 October 2021).

14. Statistical Review of World Energy 2021, 70th ed.; British Petroleum Co.: London, UK, 2021. Available online: https: //www.bp.com/content/dam/bp/business-sites/en/global/corporate/pdfs/energy-economics/statistical-review/bp-statsreview-2021-full-report.pdf (accessed on 11 August 2021).

15. Outcomes of the Glasgow Climate Change Conference-Advance Unedited Versions (AUVs) and List of Submissions from the Sessions in Glasgow. Available online: https://unfccc.int/process-and-meetings/conferences/glasgow-climate-changeconference-october-november-2021/outcomes-of-the-glasgow-climate-change-conference (accessed on 5 December 2021).

16. Smart Grids; IEA: Paris, France, 2021. Available online: https://www.iea.org/reports/smart-grids (accessed on 5 December 2021).

17. Forecast of Energy Development in the World and Russia 2019/Report of ERI RAS; Moscow School of Management Skolkovo: Moscow, Russia, 2019. Available online: https:/ / energy.skolkovo.ru/downloads/documents/SEneC/Research/SKOLKOVO_EneC_ Forecast_2019_Rus.pdf (accessed on 12 April 2021). (In Russian)

18. Vorrath, S. Top 10 technologies to double the energy efficiency, deliver zero emissions. Renew Economy. 11 March 2015. Available online: https: / / reneweconomy.com.au/top-10-technologies-to-double-energy-efficiency-deliver-zero-emissions-65 210/ (accessed on 2 August 2021).

19. Global EV Outlook 2020 Entering the Decade of Electric Drive? IEA: Paris, France, 2021. Available online: https:/ /iea.blob.core. windows.net/assets/af46e012-18c2-44d6-becd-bad21fa844fd/Global_EV_Outlook_2020.pdf (accessed on 2 August 2021).

20. Solar Energy. The National Center for Appropriate Technology. Available online: https://www.ncat.org/solar-energy/ (accessed on 4 August 2021).

21. Wind Power Facts. Available online: https:// cleanpower.org/facts/wind-power/ (accessed on 4 August 2021).

22. Gavrilov, S. Cold Roofs Take Care of the Environment. Available online: https://vseokrovle.ru/kholodnye-kryshi-zabotyatsyaob-okruzhayushhejj-srede.html (accessed on 29 July 2021). (In Russian) 
23. How an LED Uses So Much Less Energy. Available online: https://www.consumerreports.org/lightbulbs/why-an-led-uses-solittle-energy-/ (accessed on 29 July 2021).

24. Windows Lux +, Advantages of PVC Double-Pane Windows. Available online: https://okna-klas.ru/preimushhestvasteklopaketa.php (accessed on 29 July 2021). (In Russian).

25. Meier, A. Should the Next Standby Power Target Be 0-Watt? Lawrence Berkeley National Laboratory: Berkeley, CA, USA, 2021. Available online: https:/ / escholarship.org/content/qt566951pn/qt566951pn.pdf (accessed on 21 August 2021).

26. How the Thermostat Saves Energy. Available online: https://stem-energy.ru/corp-blog/kak-termoregulyator-pozvolyaetekonomit-elektroenergiyu/ (accessed on 29 July 2021). (In Russian).

27. GreenMatch, Heat Pumps: 7 Advantages and Disadvantages. Available online: https://www.greenmatch.co.uk/blog/2014/08/ heat-pumps-7-advantages-and-disadvantages (accessed on 29 July 2021).

28. Pros, Cons and Costs: Energy Star Appliances. Available online: https://www.homeadvisor.com/r/energy-star-appliances/ (accessed on 29 July 2021).

29. Sørensen, B. A history of renewable energy technology. Energy Policy 1991, 19, 8-12. [CrossRef]

30. Guo, Z.; Sun, Y.; Pan, S.Y.; Chiang, P.C. Integration of Green Energy and Advanced Energy-Efficient Technologies for Municipal Wastewater Treatment Plants. Int. J. Environ. Res. Public Health 2019, 16, 1282. [CrossRef] [PubMed]

31. He, K.; Wang, L. A review of energy use and energy-efficient technologies for the iron and steel industry. Renew. Sustain. Energy Rev. 2017, 70, 1022-1039. [CrossRef]

32. Ferrante, A.; Mochi, G.; Predari, G.; Badini, L.; Fotopoulou, A.; Gulli, R.; Semprini, G. A European Project for Safer and Energy Efficient Buildings: Pro-GET-onE (Proactive Synergy of inteGrated Efficient Technologies on Buildings' Envelopes). Sustainability 2018, 10, 812. [CrossRef]

33. Vahidi, A.; Sciarretta, A. Energy saving potentials of connected and automated vehicles. Transp. Res. Part C Emerg. Technol. 2018, 95, 822-843. [CrossRef]

34. Leng, Z.; Shuai, J.; Sun, H.; Shi, Z.; Wang, Z. Do China's wind energy products have potentials for trade with the Belt and Road countries?-A gravity model approach. Energy Policy 2020, 137. [CrossRef]

35. Xi, L.; McElroy, M.B.; Kiviluoma, K. Global potential for wind-generated electricity. Proc. Natl. Acad. Sci. USA 2009, 106, 10933-10938.

36. Chaurasiya, P.K.; Warudkar, V.; Ahmed, S. Wind energy development and policy in India: A review. Energy Strat. Rev. 2019, 24, 342-357. [CrossRef]

37. Shoaib, M.; Siddiqui, I.; Rehman, S.; Khan, S.; Alhems, L.M. Assessment of wind energy potential using wind energy conversion system. J. Clean. Prod. 2019, 216, 346-360. [CrossRef]

38. Shahsavari, A.; Morteza, A. Potential of solar energy in developing countries for reducing energy-related emissions. Renew. Sustain. Energy Rev. 2018, 90, 275-291. [CrossRef]

39. Bódis, K.; Kougias, I.; Jäger-Waldau, A.; Taylor, N.; Szabó, S. A high-resolution geospatial assessment of the rooftop solar photovoltaic potential in the European Union. Renew. Sustain. Energy Rev. 2019, 114. [CrossRef]

40. Ermolenko, B.V.; Ermolenko, G.V.; Fetisova, Y.A.; Proskuryakova, L.N. Wind and solar PV technical potentials: Measurement methodology and assessments for Russia. Energy 2017, 137, 1001-1012. [CrossRef]

41. Puebla, J.; Kim, J.; Kondou, K.; Otani, Y. Spintronic devices for energy-efficient data storage and energy harvesting. Commun. Mater. 2020, 1. [CrossRef]

42. Climate Change 2021: The Physical Science Basis. Contribution of Working Group I to the Sixth Assessment Report of the Intergovernmental Panel on Climate Change; IPCC: Geneva, Switzerland, August 2021.

43. Ploetz, R.; Rusdianasari, R.; Eviliana, E. Renewable Energy: Advantages and Disadvantages. In Proceedings of the Forum in Research, Science and Technology, Palembang, Indonesia, 18-19 October 2016.

44. Advantages and Disadvantages of Using Renewable Energy. Available online: https://terrapass.com/blog/advantages-anddisadvantages-of-using-renewable-energy (accessed on 14 September 2021).

45. Baraniuk, C. How China's giant solar farms are transforming world energy. BBC. 4 September 2018. Available online: https: //www.bbc.com/future/article/20180822-why-china-is-transforming-the-worlds-solar-energy (accessed on 5 December 2021).

46. The Future of Hydrogen; International Energy Agency (IEA): Paris, France, 2019. Available online: https: / /iea.blob.core.windows. net/assets/9e3a3493-b9a6-4b7d-b499-7ca48e357561/The_Future_of_Hydrogen.pdf (accessed on 14 August 2021).

47. Hydrogen Boiler. Available online: https://www.worcester-bosch.co.uk/hydrogen (accessed on 14 August 2021).

48. Vitovalor PT2. Available online: https://www.viessmann.co.uk/products/combined-heat-and-power/fuel-cell/vitovalor (accessed on 17 August 2021).

49. Global Demand for Pure Hydrogen, 1975-2018; IEA: Paris, France, 2019. Available online: https://www.iea.org/data-and-statistics/ charts/global-demand-for-pure-hydrogen-1975-2018 (accessed on 16 August 2021).

50. Advantages and Disadvantages of Hydrogen Energy, Boiler Guide. Available online: https://www.boilerguide.co.uk/articles/ advantages-disadvantages-hydrogen-energy (accessed on 19 August 2021).

51. Watson, S. What are the Pros and Cons of Hydrogen Energy? Available online: https://science.howstuffworks.com/ environmental/green-science/pros-and-cons-of-hydrogen-energy.htm (accessed on 18 August 2021). 
52. Hydrogen: A Renewable Energy Perspective; International Renewable Energy Agency: Abu Dhabi, United Arab Emirates, 2019. Available online: https://www.irena.org/_/media/Files/IRENA/Agency/Publication/2019/Sep/IRENA_Hydrogen_2019.pdf (accessed on 19 August 2021).

53. Hydrogen Explained. Available online: https://www.eia.gov/energyexplained/hydrogen/ (accessed on 19 August 2021).

54. What's the Difference Between Gray, Blue and Green Hydrogen? Available online: https://www.jdpower.com/cars/shoppingguides/whats-the-difference-between-gray-blue-and-green-hydrogen (accessed on 19 August 2021).

55. Casey, J.P. Will China do for Hydrogen What It Did for Solar Power? Future Power Technology, Inc.: London, UK, 2021. Available online: https:/ / www.power-technology.com/features/will-china-do-for-hydrogen-what-it-did-for-solar-power/ (accessed on 10 August 2021).

56. Experts Explain Why Green Hydrogen Costs Have Fallen and Will Keep Falling. Available online: https://www.spglobal.com/ marketintelligence/en/news-insights/latest-news-headlines/experts-explain-why-green-hydrogen-costs-have-fallen-andwill-keep-falling-63037203 (accessed on 19 August 2021).

57. Sonal Patel, Countries Roll Out Green Hydrogen Strategies, Electrolyzer Targets, Power. 2021. Available online: https://www. powermag.com/countries-roll-out-green-hydrogen-strategies-electrolyzer-targets/ (accessed on 19 August 2021).

58. Hydrogen Strategy for Canada. Available online: https://www.nrcan.gc.ca/changements-climatiques/hydrogen-strategy/23080 (accessed on 19 August 2021).

59. National Green Hydrogen Strategy; Ministry of Energy, Government of Chile: Santiago, Chile, 2020. Available online: https:/ /www. google.ru/url?sa=t\&rct=j\&q=\&esrc=s\&source=web\&cd=\&ved=2ahUKEwjesZO0var0AhWpw4sKHevZAdsQFnoECAMQAQ\& url=https $\% 3 \mathrm{~A} \% 2 \mathrm{~F} \% 2 \mathrm{Fenergia.gob.cl} \% 2 \mathrm{Fsites} \% 2 \mathrm{Fdefault} \% 2 \mathrm{Ffiles} \% 2 \mathrm{Fnational}$ green_hydrogen_strategy_-_chile.pdf\&usg= AOvVaw0xaJg_mmBcUslTnnfYnBzY (accessed on 19 August 2021).

60. Morton, A. Australia's first fully renewable 'hydrogen valley' slated for NSW coal heartland. The Guardian, 17 May 2021 ; 1756-3224.

61. Hydrogen. Available online: https://www.bp.com/en/global/corporate/energy-economics/energy-outlook/demand-by-fuel/ hydrogen.html (accessed on 19 August 2021).

62. Holbrook, E. EnergyCAP, Study Says Global Green Hydrogen Production to Skyrocket 57\% to 2030. Available online: https: //www.environmentalleader.com/2021/01/study-says-global-green-hydrogen-production-to-skyrocket-57-to-2030/ (accessed on 5 December 2021).

63. Sönnichsen, S. Global Hydrogen Production Outlook by Type 2015-2050. Available online: https:/ / www.statista.com/statistics / 859104/hydrogen-production-outlook-worldwide-by-type/ (accessed on 5 December 2021).

64. Caspersen, M. The Hydrogen Trajectory. Available online: https://home.kpmg/xx/en/home/insights/2020/11/the-hydrogentrajectory.html (accessed on 5 December 2021).

65. van Renssen, S. How Green Hydrogen Will Grow Up into a Global Market. Available online: https://www.energymonitor.ai/ tech/hydrogen/how-green-hydrogen-will-grow-up-into-a-global-market (accessed on 5 December 2021).

66. Flowers, S. Future Energy—Green Hydrogen. Could It Be a Pillar of Decarbonization. Available online: https://www.woodmac. com/news/the-edge/future-energy-green-hydrogen/ (accessed on 5 December 2021).

67. Buli, N. Green Hydrogen to Account for $20 \%$ of European Power Demand by 2050—Statkraft. Available online: https://www. reuters.com/business/energy/green-hydrogen-account-20-european-power-demand-by-2050-statkraft-2021-10-21/ (accessed on 5 December 2021).

68. Scott, M. Green Hydrogen, Forbes, The Fuel Of The Future, Set For 50-Fold Expansion. Available online: https://www.forbes. com/sites/mikescott/2020/12/14/green-hydrogen-the-fuel-of-the-future-set-for-50-fold-expansion/?sh=6f5485306df3 (accessed on 5 December 2021).

69. Akaev, A.A.; Davydova, O.I. A Mathematical Description of Selected Energy Transition Scenarios in the 21st Century, Intended to Realize the Main Goals of the Paris Climate Agreement. Energies 2021, 14, 2558. [CrossRef]

70. Akaev, A.A.; Sadovnichii, V.A. Mathematical model of population dynamics with the world population size stabilizing about a stationary level. Dokl. Math. 2010, 82, 978-981. [CrossRef]

71. Kapitsa, S.P. Essay on the theory of population growth. In Demographic Revolution and Information Society; M Nikitsky Club: Moscow, Russia, 2008. Available online: https://books.google.ru/books?id=419QAQAAIAAJ (accessed on 22 April 2021). (In Russian)

72. United Nations World Population Prospects. Available online: https:// population.un.org/wpp/ (accessed on 15 April 2021).

73. Plakitkin, Y.A. Patterns of Innovative Development of the World Economy: Energy Modes of the 21st Century; SPb RANS: Saint Petersburg, Russia, 2012; p. 120. ISBN 978-5-91918-194-1. (In Russian)

74. Marchetti, C.; Nakicenovic, N. The Dynamics of Energy Systems and the Logistic Substitution Model, RR-79-13; International Institute for Applied Systems Analysis: Laxenburg, Austria, 1979. Available online: http://pure.iiasa.ac.at/1024 (accessed on 17 April 2021).

75. Transforming the Energy System and Holding the Line on Rising Global Temperatures; International Renewable Energy Agency: Abu Dhabi, United Arab Emirates, 2019. Available online: https:/ /www.irena.org/-/media/Files/IRENA/Agency/Publication/20 19/Sep/IRENA_Transforming_the_energy_system_2019.pdf (accessed on 21 April 2021).

76. World Energy Scenarios, The Future of Nuclear. Available online: https://www.worldenergy.org/publications/entry/worldenergy-scenarios-2019-the-future-of-nuclear-diverse-harmonies-in-the-energy-transition (accessed on 21 August 2021). 
77. Shell New Lens Scenarios A Shift in Perspective for a World in Transition. Available online: https://www.google.ru/url?sa= t\&rct=j\&q=\&esrc=s\&source=web\&cd=\&ved=2ahUKEwih_7mr-4ftAhVMr4sKHT_tBAEQFjABegQIAxAC\&url=https $\% 3 A \%$ 2F\%2Fwww.shell.com $\% 2$ Fcontent $\% 2$ Fdam $\% 2$ Froyaldutchshell $\% 2$ Fdocuments $\% 2 F$ corporate $\% 2 F s c e n a r i o s-n e w d o c . p d f \& u s g=$ AOvVaw2yKUrs_ZGNsFk9icrtWoM1 (accessed on 21 August 2021).

78. ExxonMobil The 2019 Outlook for Energy. Available online: https://corporate.exxonmobil.com/-/media/Global/Files/outlookfor-energy/2019-Outlook-for-Energy_v4.pdf (accessed on 21 August 2021).

79. Akaev, A.A. The Stabilization of Earth's Climate in the 21st Century by the Stabilization of Per Capita Consumption. In The Oxford Handbook of the Macroeconomics of Global Warming; Semmler, B.W., Ed.; Oxford University Press: New York, NY, USA, 2014; pp. 499-554. [CrossRef]

80. International Energy Agency. Energy Technology Perspectives 2010: Scenarios and Strategies to 2050; OECD Publishing: Paris, France, 2009. [CrossRef]

81. Kuykendall, K. Carbon Capture and Storage Projects on the Rise Gobally-Global CCS Institute. Available online: https:/ / www.spglobal.com/marketintelligence/en/news-insights/latest-news-headlines/carbon-capture-and-storageprojects-on-the-rise-globally-8211-global-ccs-institute-61531550 (accessed on 17 September 2021).

82. Disadvantages of Carbon Capture. Available online: https://theclimateconnection.org/disadvantages-of-carbon-capture/ (accessed on 17 September 2021).

83. Dooley, J.J.; Dahowski, R.T.; Davidson, C.L.; Wise, M.A.; Gupta, N.; Kim, S.H.; Malone, E.L. Carbon Dioxide Capture and Geologic Storage: A Core Element of a Global Energy Technology Strategy to Address Climate Change; The Global Energy Technology Strategy Program: College Park, MD, USA, 2006.

84. Tarko, A.M. Anthropogenic Changes of the Global Biosphere Processes. Mathematical Modelling; Fizmatlit: Moscow, Russia; p. 232. Available online: https:/ / www.researchgate.net/publication/312093195_Tarko_AM_Antropogennye_izmenenia_globalnyh_ biosfernyh_processov_Matematiceskoe_modelirovanie_-_M_Fizmatlit_2005_-_232_s_Tarko_AM_Anthropogenic_Changes_ of_the_Global_Biosphere_Processes_Mathematical_Mo (accessed on 30 March 2021). (In Russian) 